\title{
Scenes of Offering Palm Dates in Egyptian Temples during the Græco-Roman Period Sara El-Sayed Kitat
}

Tour Guiding Department - Faculty of Tourism and Hotels - Alexandria University

\begin{abstract}
:
Offering palm dates is a remarkable offering scene in the Egyptian temples during the Græco-Roman period. Eleven scenes are found depicting the Ptolemaic king or the Roman emperor presenting palm dates to the deities. After the reign of Trajan, these scenes were no more attested. Palm dates were sacred offerings of Osiris during Khoaik festival. Therefore, the image of Osiris dominated the majority of the scenes. Offering palm dates to Isis was based on her role in reuniting Osiris' body. Apis and Horus were depicted in the oldest scene of dates offering in front of Ptolemy IV in Edfu temple. Harendotus was represented receiving this offering in two scenes in Philae temple. Thoth of Pnubis was depicted in a solemn scene receiving palm dates in Philae temple. Ptah is represented receiving palm dates in the temple of Tod. Shu and Tefnut are depicted receiving palm dates from Augustus in El-Qal'a temple.
\end{abstract}

\section{Dates in the Ancient Egyptian Language and Religion:} $\therefore 0$

Dates were named in the ancient Egyptian language as

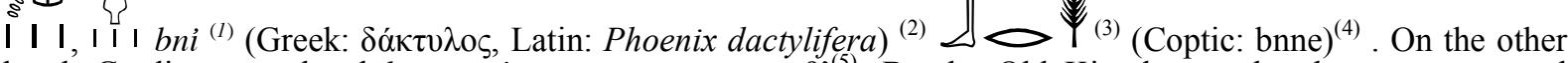
hand, Gardiner translated $b n q$ as "a sweet tasting root? ${ }^{,(5)}$. By the Old Kingdom, palm dates were named $\int 10$

o०० bnq.wt in the Pyramid Texts ${ }^{(6)}$.They were one of the important ancient Egyptian food ${ }^{(7)}$ and a crucial source for carbohydrates and proteins ${ }^{(8)}$. Dates were used as fresh or dried fruits, sweetening agent, and in manufacturing date wine ${ }^{(9)}$. This is because of its remarkable nutritional value and being easy to be cultivated ${ }^{(10)}$. Stone and wooden date-shaped objects dating back to the Predynastic Period were discovered in Egypt ${ }^{(11)}$. Stone samples of reclinata palm dates were discovered in Egypt and now preserved in Florence Museum. Stones of this type of palms were once found in Kharga oasis. However, reclinata palms which grow in a humid climate disappeared from Egypt since the obvious climatic changes ${ }^{(12)}$.

Dates began to be used as funerary offerings as early as the second dynasty ${ }^{(13)}$. The term

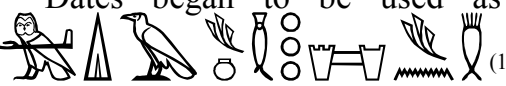

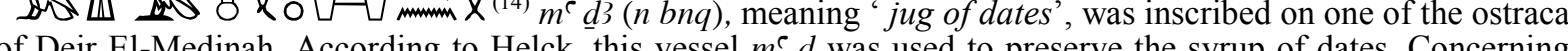
to Helck, this vessel $m^{r} d$ was used to preserve the syrup of dates. Concerning fresh dates, they were preserved in vessels called $m^{e} \underline{d} 3^{(15)}$. On the contrary, Gardiner rather believes that in $x$

II $m^{e} \underline{d}$ s was mainly a measuring unit for palm dates. This title was mentioned in Harris medical

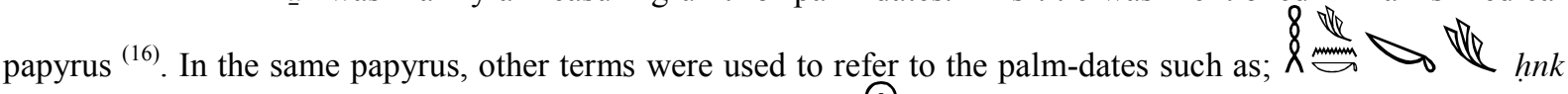
which apparently means 'a cluster cut off for dates ${ }^{,(17)}$, and dates'. The term mmm $n \underline{d}^{\top}$ refers also to dates ${ }^{(18)}$.

Wallert referred to the date palms which were mentioned in the sources of certain solar temples in Egypt revealing by this way their solar nature ${ }^{(19)}$. In the sun temple of Niusere, date palms were depicted among other sort of trees sacred to god $\mathrm{Re}^{(20)}$. In spell 325 of the Coffin Texts, the sun god rises from the date palm, being therefore placed in comparison with the two sycamores in the temple of Heliopolis ${ }^{(21)}$. Part of this spell says; 'The Eye of Atum appeared from the bb.t plant as surely as the Eye of Atum elevated itself $d$ from the date palm, (22). Furthermore, different texts mention the grain offerings by the name smnw or mention ' $n h w$ and $n b w$ as palm dates' offerings ${ }^{(23)}$. During the twenty-fifth dynasty, King Taharqa dedicated in the Nubian temple of Kawa his father Amun-Re; 'the golden face of a ram (as the sacred animal of Amun-Re) over date palms, and dedicated a golden statuette of Amun Re, the master of Gem-aton, over a date palm, (24). By the Ptolemaic period, the Egyptian god Heh, god of eternity, was depicted holding two palm ribs in his hands. These ribs were ?

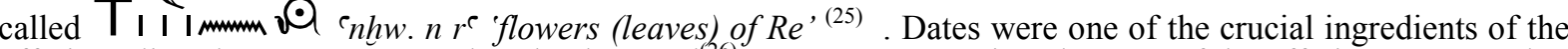
offerings' lists that were presented to the deceased ${ }^{(26)}$. Dates were mentioned as one of the offerings presented to sun god Re in Egypt. For instance, Ramses III dedicated "65,480 dates to Re at Heliopolis"(27).

\section{Scenes of Offering Palm Dates:}

Priests preferred to offer palm dates to their deities by making the king offer this type of fruits to the gods (28). Offering palm dates formed a remarkable offering scene in the Egyptian temples during the Græco-Roman period. Eleven scenes are found depicting the ruler of Egypt, whether the Ptolemaic king or the Roman emperor, presenting palm dates to the Egyptian deities. Being a pure religious ritual, these scenes could be categorized according to the depicted deity receiving the palm dates as follows; 


\subsection{Scenes of Offering Palm Dates to God Osiris:}

In the Book of the Dreams, palm dates symbolized the abundance of the Nile. Part of this book says; 'when one sees in his dreams that he is picking palm dates, this means good, subsistence that the God will give him ${ }^{(29)}$. Since being one of the main gods of the Nile and inundation in ancient Egypt ${ }^{(30)}$, the connection between god Osiris and palm dates is obviously logic. According to $\mathrm{Ch}$. Thiers, the close connection between the offering of the palm date containers and the $(r d w)$ of Osiris or Geb is originally because of its medical healing properties. Thus, the artist might reflect both the ritual and medical concept of this type of Osirian offerings ${ }^{(31)}$.

It is worth to note that the word $\left.r d w \sim\right|^{(32)}$ was used in the title of certain scenes of palm offering instead of the word bnq (see fig.6). The first word refers either to the water of the Nile or the wine ${ }^{(3)}$. According to Plutarch, the Egyptians regarded Osiris to be their primitive ocean. Thus, the dead king, being identified with Osiris, used the fresh waters of Osiris to return to life again ${ }^{(34)}$. The offered fresh water of Osiris was known as

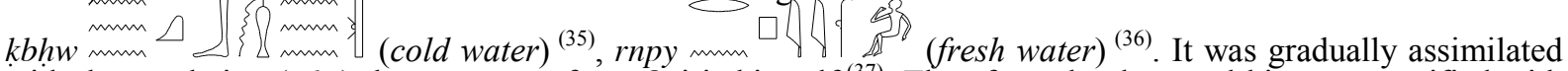
with the exudation $(r \underline{d} w)$ that came out from Osiris himself ${ }^{(37)}$. Therefore, the deceased king was purified with the fresh water of Osiris to be resurrected once more in the Otherworld ${ }^{(38)}$. A Ptolemaic papyrus described rituals of Osirian ceremonies practiced in Cynopolis in Middle Egypt. One of these rituals is placing the so-called $r \underline{d} w$ of Osiris, compiled by his son Horus, inside a vase called $s n w^{(39)}$.

Dates began to be used in various medical prescriptions ${ }^{(40)}{ }^{\circ}$. Thus, dates' containers were possibly used to receive a sort of dates syrup which was used as an ointment. This syrup has been intended to heal the wounds and to re-solder the flesh. This medical role might be the origin behind the symbolic Osirian role of the palm dates in regenerating of the god ${ }^{(41)}$.

Dates palms were one of the plants of Egypt that were specially associated with the concept of resurrection. They were associated with the cult of god Re symbolizing the victory of life over death. This symbolism was expressed through the scenes of the 'Butic Burials' found in the tombs of Saqqara and Thebes, dating back to the eighteenth and twentieth dynasties ${ }^{(42)}$. In addition, date palms were one of the sacred trees found in the scenes of the Osirian Mound of Creation which are similar in shape to the scenes of the 'Butic Burials' (43). Beside other sacred trees, palm trees were located in between, separating the burial places in ancient Egypt from the surrounding territories forming by that way a separate line between Life and death ${ }^{(44)}$. Spells from the Pyramid Texts reveal the high nutritional quality of this type of food for the deceased king who is identified with Osiris $^{(45)}$. For example, part of spell 409 which is called 'food spell' says; 'the king lives from trees with sweet fruits $^{(46)}$.

In ancient Egyptian religion, the eye of Atum, or mainly, the eye of the sun, elevated itself from the $b b-t$ plant and from a date palm ${ }^{(47)}$. This word was interpreted by H. Kees as 'masturbation' rather than 'date palm' (48). This opinion was accepted by Cauville who believes that the term bnq rather refers to the vessel in which the dates are presented. In this vessel, a mixture of amalgamated dates $(\check{s} b \breve{s} b)$ was placed. This mixture was used to unite the bodily parts of Osiris to rejuvenate it (srnp) and to make it live $\left(s^{\top} n h\right)$ while shaping it $(n b)$. The expression $t w t d t$ which means 'gathering, assembling the body' evidently refers to the essential phase of the Osirian myth ${ }^{(49)}$. Texts accompanying the scene of dates' offerings mention the form of Osiris mixed with barley $(n b)$. In addition to other verbs in the texts such as; $t w t \circ]_{(50)}$ and srnp obviously throw light on the Osirian myth and his body dismemberment ${ }^{(52)}$.

and the word the generative powers of creation ${ }^{(56)}$. Like the phoenix bird which rises from its ashes, palms impetrate themselves. This might be the reason behind consecrating palm dates to god Osiris; the god of constant alternation ${ }^{(57)}$. Dates are regarded as emersion from the Osirian body and enabled the god to be transformed into a sacred work that cannot be revealed ${ }^{(58)}$. Pliny assumed that the name of the phoenix bird was originally driven from the name of the fruit ${ }^{(59)}$.

Renewing the life and youth of the deity reveal's the function of palm dates as one of the sacred offering to Osiris during his yearly festival of Khoaik ${ }^{(60)}$. The germination of the seeds symbolized the resurrection of Osiris. This practice referred to the function of Osiris as a water, grain, and funerary god ${ }^{(61)}$. The body of Osiris embodied the earth from which water came out. This water was named 'the fluid coming out of Osiris', and the 'sweat of Osiris ${ }^{, 62)}$. Sand seeds refer to the sand which was mixed with barley to mold the sacred 'Osiris' beds' in the month of Khoaik ${ }^{(63)}$. This bed was pictorially represented in the first Osirian chapel in Denderah temple. The syrup of dates was apparently used to manufacture Osiris beds which were made of barley, sand or mud, and certain liquids ${ }^{(64)}$

The first mention of palm offerings ' $m^{\complement} \underline{d} \underline{3} n b n q^{\prime}$ as a remarkable Osirian ritual was in Edfu temple during the Ptolemaic period and had not appeared before that era. Osiris appeared receiving palm dates in mainly eight scenes; two scenes in Edfu temple, three in Denderah temple, and three in the temple of Philae ${ }^{(65)}$. He was depicted in four of them receiving this type of offerings alone. In the other four scenes he was accompanied with other deities.

In Edfu temple, there are two scenes for offering palm dates to Osiris alone. They are located on the exterior wall of naos ${ }^{(66)}$. The first one is depicted on the western wall, the fourth register (second scene) (fig. 1) ${ }^{(67)}$ and the other is depicted on the eastern wall, the fourth register (second scene) (fig.2) ${ }^{(68)}$. According to the 
accompanying texts, these offerings represent the creation of the time and symbolize the regeneration of Osiris, lord of Busiris and Abysos ${ }^{(69)}$.

In the first scene of Edfu temple, Ptolemy VIII Eurgetes II (169 B.C.-116 B.C.) is depicted holding a vessel 5

of dates in front of god Osiris and wearing the Red Crown of Lower Egypt . The deity is depicted seated on the throne and crowned with the composite crown of sun disk surmounted by two ostrich feathers (Andjeti Crown) left hand (fig.1). The whole scene is titled 'offering dates' vessels, ( ${ }^{1 / 1)}$. Part of the text says; 'receive seeds of life to be alive (you) seeds of youth to renew your youth every year. These are seeds of gold that you created from which your soul emerged and united with sand seeds. Your father placed them in the vessel' ${ }^{72)}$.

In this scene, Ptolemy VIII says; 'son of šnt'yt the father of fathers, the strong bull, who makes rites for Osiris... who makes rites for the souls of Iounu.... came to you, lord of gods, the youthful bull, who renewed his youth in the palace of gold ${ }^{\text {,73) }}$. The chapel or palace of gold was used to refer to the workshop of manufacturing statues which were used for the ritual of Opening the Mouth in Memphis. The corpse of the deceased was also preserved in this place before its burial. Moreover, the statue of Osiris which was used during the Festival of Khoaik was made in this place ${ }^{(74)}$. As for god Osiris Wennefer, he says 'I will give you the crown of justification that shines on your forehead and the courage of Upper Egypt that shines on your head. words are spoken by Osiris lord of Busiris the great god who resides at Behdet lord of eternity ... Wennefer the triumphant ${ }^{(75)}$.

In the second scene of Edfu temple, Ptolemy VIII Eurgetes II (169 B.C.-116 B.C.) is also depicted presenting palm dates to god Osiris ${ }^{(76)}$. The king is depicted standing and crowned here with the White Crown of Upper Egypt . As for god Osiris, he is depicted seated on the throne wearing the Atef Crown . He holds the $w 3 s$ scepter $h$ in his right hand the ' $n h$ sign 7 in his left hand (fig.2). The scene is entitled as 'Offering dates' vessels'. Part of the text says; ' the secret emanations out of your flesh - it is a mix prepared by your sister Isis who gathered your body at its time, they come to you and they keep your image and they circulate protecting you, ${ }^{(77)}$.

Concerning King Ptolemy VIII, he presents his offerings with the following words; 'The steward of the fields of Shu who makes the fields green again and fertilizes the land by his magical knowledge...... I bring you the seeds offerings gathered together to double your desire so that you will be satisfied in your heart, you the god who will make the fruit the grains and created the wheat to make men alive, ${ }^{(78)}$. Osiris appears here in the form of Osiris Khentimenti. The accompanying texts of Osiris say; 'words are spoken by Osiris who presides over the West, the great chief god of Abydos, great loun who has Edfu, the royal offspring who wears the white crown. He was in his mother's womb and has reigned over the throne since he was born: welcome burial man who gives offerings to gods and men! rejoiced to see them: large is my place, strengthened by your magnificence. I submerge your steps with the water of ... to supply the banks of the Haou-nebout ${ }^{\text {(79) }}$.

In the temple of Dendreah, there are two scenes representing the offering of palm dates to Osiris alone. The first one is on the northern wall of the third eastern chamber (F) (Hall of Sokar), first register, third scene, the Ptolemaic king (unidentified, apparently one of the late Ptolemaic kings) is depicted presenting a vessel full of palm dates to god Osiris (fig.3) ${ }^{(80)}$. The king is depicted in a standing positing and crowned with the Double Crown of Upper and Lower Egypt Crown of Upper and Lower Egypt . Concerning god Osiris, he is depicted standing and crowned with Atef Crown The accompanying text reads;

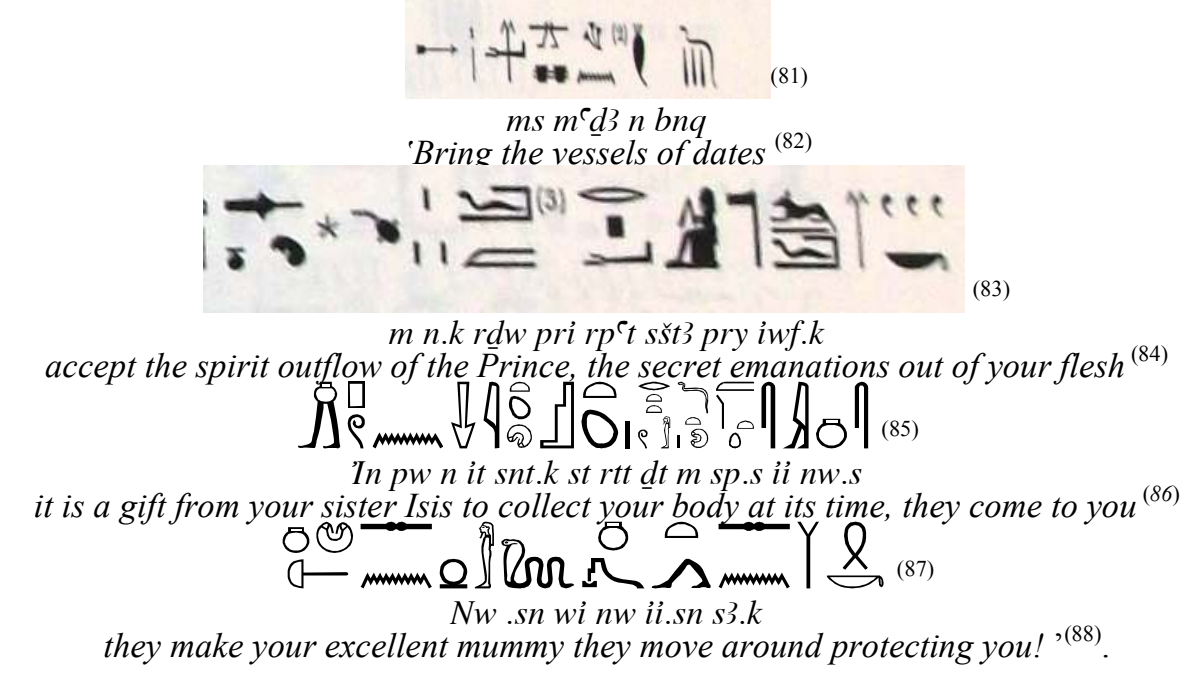


The Ptolemaic king says; 'hail to the perfect god who was raised by the two sisters, the burial man Ounennefer who raises the seeds of life for the ka of the burning bull in his chapel who shapes his statue in Dandara the master of crowns son of Re! ${ }^{(89)}$. Concerning god Osiris, he appears here in the form of god Osiris Wenenefer. He says: 'Words are spoken by Osiris the triumphant Ounenenefre, the great god who resides in Dendera, the royal child who wears the white crown with the uraeus on his forehead, the two sanctuaries of the gods possess the effigies: I rejuvenate your flesh ${ }^{\text {(90) }}$.

Another scene in the temple of Denderah shows offering palm dates to Osiris. This scene is located on the southern wall of the third eastern chamber (F) (Hall of Sokar), first register, third scene (fig.4) (91). The accompanying text says; 'receiving vessels of dates accept (... ..) (so that) you renew your life every year!"(92). Similar to the previous one, the Ptolemaic king (unidentified, apparently one of the late Ptolemaic kings) is depicted in a standing positing and crowned with the Double Crown of Upper and Lower Egypt . God Osiris is represented in the standing pose and crowned with Atef Crown right hand and the $w 3$ s scepter $h$ in the left one.

The accompanying text says; 'Bring the vessels of dates, accept ...( so that) you renew your life every day, we do for you the work (.....) his image to hide your mummy from the gods. When Re appears, he shows himself in the sky to illuminate your body on time'. The depicted Ptolemaic king addresses to Osiris the following words: 'He who enters as an ouab in the temple of Osiris to perform the ritual of Osiris, long live the perfect sovereign god of Egypt the living flesh of Iun, the divine purifier excellent in his work without knowing ... of whom the flesh is united, who makes the excellent forms of the one who presides over the west, the master of the crowns son of Re ${ }^{,(93)}$. As for go Osiris, he also appears in the form of Osiris Wennefer like the previous scene. He says; 'Words are spoken by Osiris, the triumphant Ounennefer, the great god who resides at Denderah, the master of Busiris, the sovereign of Abydos, the king in heaven, the prince on earth, the great monarch of the necropolis. I give you both sanctuaries in adoration before your ka and (I make) that you renew each year ${ }^{(94)}$.

\subsection{Offering Palm Dates to Osiris accompanied with other deities:}

In addition to a the previous mentioned scenes, other scenes depict this type of offering being presented to number of deities led mainly by god Osiris. The deities which were depicted beside Osiris in these scenes are; Isis, Thoth of Pnubis, and Harendoutes.

\subsubsection{Offering Palm Dates to Osiris and Isis:}

Two scenes depict goddess Isis side by side with her consort Osiris to receive palm dates from the Roman emperor; one is found in the temple of Denderah, and the other is located in the temple of Isis at Philae. Isis the consort of god Osiris played a great role in re-uniting the body of her husband ${ }^{(95)}$.

The first scene of Osiris and Isis receiving palm dates is located in Denderah temple. Among its various names, Dendera was named $\square \sqsupset \mathrm{l}$ the goddess, ${ }^{,(96)}$. In addition, one of the ancient epithets of this goddess was 'mistress of date-palms, Depending on this title, which came originally from a text from Kom El-Hisn, Sethe concluded that this deity was originally a tree-goddess. In spell 68 of the Book of the Dead, Hathour appears as a goddess of date palms: "I live under the branches of the palms of Hathour, which sovereigns over the wide sun disc"(98). In Egyptian myth, the assimilation between Isis and the tree goddess Hathour is obviously attested ${ }^{(99)}$.

The first scene is located in the temple of Denderah, mainly on the exterior western wall of the naos of the temple $(\mathrm{H})$, fourth register, thirteenth scene (fig.5) ${ }^{(100)}$. This scene represents the Roman emperor Augustus ${ }^{(101)}$ wearing the Atef Crown Andjeti Crown $14[19$ while his consort is represented with her Hathouric crown. The two deities are figured seated on the throne and holding the ${ }^{n} h \mathrm{~s}$ sign $f$ in their left hands. Osiris holds the $w 3 s$ scepter $h$ in his right hand while Isis holds the $w 3 \underline{\underline{d}}$ sign in her right hand.

The scene is entitled as;
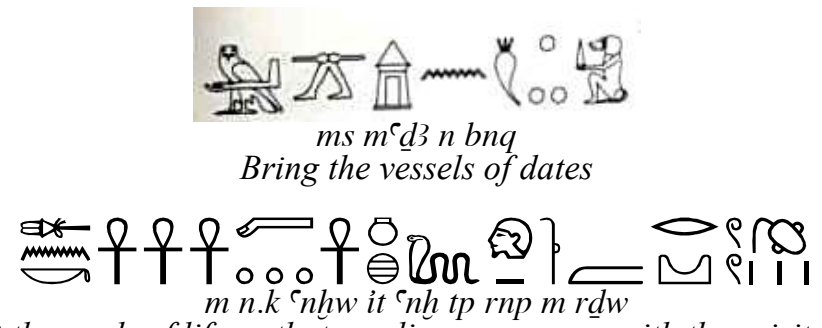

accept the seeds of life so that you live every year with the spirit outflow 


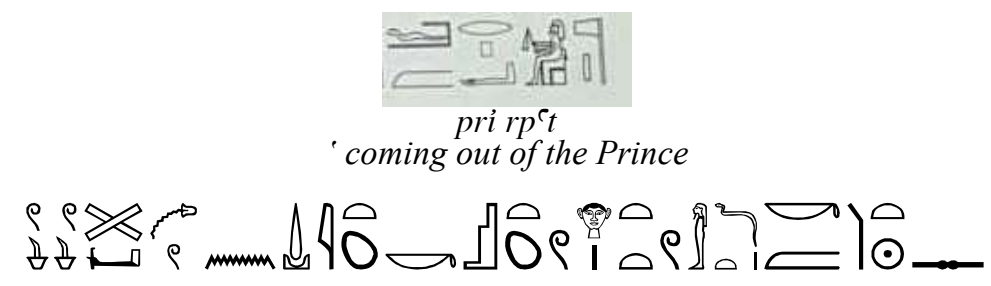

3mi šbn n snt.k st hr twt dt.km sp.s

It is a mixture (prepared) by your sister Isis (who is) gathering your body at its time ${ }^{,(102)}$.

Part of the accompanying text of Augustus is read: 'son of Shentayt,, intendant of fields of Shu ........I come to you, lord of gods, the youthful bull, who renewed his youth in the palace of gold, I bring to you the seeds offerings gathered at your desire in such a way that you heart is satisfied ${ }^{(103)}$. As for god Osiris, he says :'Words are spoken by Osiris master of Busirs, the great god who resides in Denderah, the ruler of eternity came to existence at the beginning....I am the owner of the venerable Djed, master of the royalty like Horus, I take barley reunited to the grains and I rejoice to see my image, I give you the fertile country that produces the crops without growing weeds among them ${ }^{(104)}$. Finally, goddess Isis Shentayt is accompanied with the following inscriptions: 'words are spoken by the great Isis, the divine mother of venerable Sntayt the venerable one who resides in Busiris, the daughter of Geb born by Nut life giver in Denderah, ${ }^{(105)}$.

The second scene of Osiris and Isis receiving palm dates is found in the temple of Isis of Philae, the first scene is located in the exterior western wall of the naos in the temple of Isis, second register, fourth scene (fig.6) ${ }^{(106)}$. The Roman emperor Augustus (27 B.C- 14 AD) is depicted standing and presenting palm dates to both Osiris Sokar and Isis Shentayt. Augustus is depicted wearing a composite crown consisting of a Red Crown of Lower Egypt and the Atef Crown divine emblems namely the $n h h$ sign in his right hand and $w 3 s$ scepter $h$ in his left hand. Osiris Sokar is depicted here in the form of a falcon headed man and wearing the Atef Crown In addition, Isis is depicted sitting before Osiris and crowned with a composite crown consisting of the Hathouric crown and the hieroglyphic sign of her name, namely st $[$. She holds the ' $n h$ sign $f$ in her right hand. The Roman emperor Augustus is offerings palm dates to both Osiris and Isis.

The scene is named;

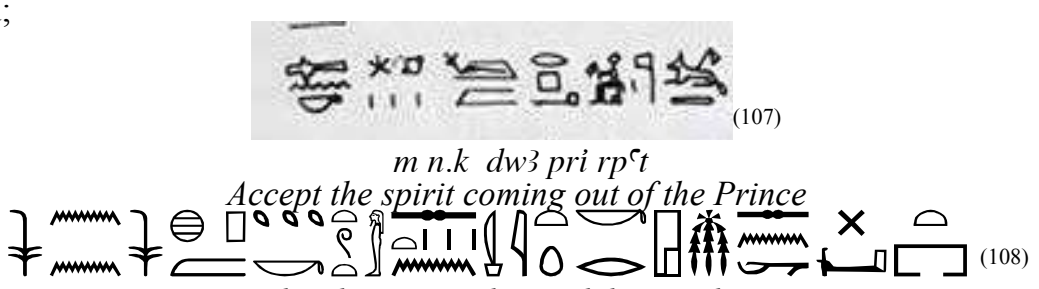

nn hpr.k twt.i st.n $k$ nmit.k hwt ms hpš prt

'these secret emanations are created from your flesh, I I gather them for your sister in the castle of the vigorous'

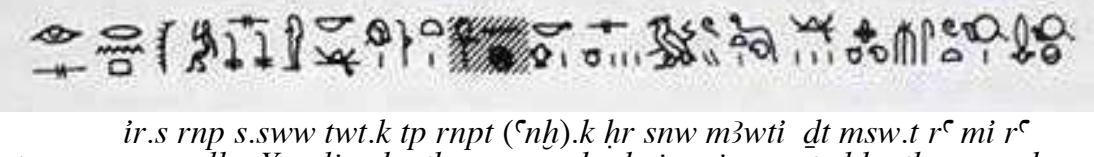

She rejuvenates you annually. You live by them, your body is rejuvenated by them, and you are born like Re every day, (111)

Emperor Augustus says: 'Successor of Geb, giving birth to the efficient; As long as the son of Re, Cesar on the hill of Osiris, the living image of the son of Isis, is revealing the seeds of life, gathering the spirits of the god, shaping his father with the barley of ..., and the master of the image, the founder of the divine flesh (112). Concerning god Osiris, his accompanying inscriptions say: words are spoken by Osiris Sokar, the great god who resides in Shetyt, the king of the gods, the ruler of Biggeh, the venerable mummy in Biggeh)....as long as Re (is) in Biggeh its holy temple and pure island is making (burial ritual) for his ka, while his son Horus carries his body as the imyou-khent priests do, and the very great god who rejuvenates on his throne and renews himself (annually) ${ }^{,(113)}$. Goddess Isis says: 'words are spoken by Isis, gifted with life, mistress of Abaton mistress lady of Philae, Shentayt who rejuvenates her brother annually and protected her body in the house of life, ${ }^{\text {,(114). }}$

\subsubsection{Scenes of Palm Dates Offerings to Osiris, Isis, and Harendotus:}

In the temple of Isis at Philae, a remarkable scene shows the Roman emperor Tiberius (14 A.D.-37 A.D.) presenting a jar of palm dates to three deities; Osiris, Isis, and Harendotus. This scene is located in the second eastern colonnade, hall of Tiberius, south wall, upper register (fig.7) ${ }^{(115)}$. Tiberius is depicted presenting palm dates in the presence of Osiris, Isis, and Harendotes ${ }^{(116)}$. The scene is titled: 


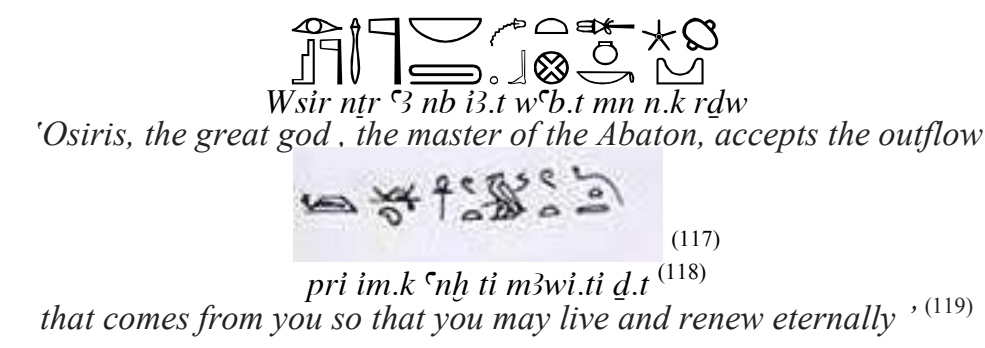

Tiberius says:" King of Upper and Lower Egypt the Autocrat, on his throne, the excellent sovereign, beloved of gods is offering the recipients of dates to his master to appease his heart with his spirits, the son of Isis who rejuvenated his father in the temples of Upper and Lower Egypt ${ }^{(120)}$. Osiris say: 'words are spoken by Osiris the great master god of the Abaton the venerable effigy master of Philae who rejuvenates his spirits annually so that the god lives eternally, the (Prince) appeared in (Iw rkt) as a (great) god (master of the Abaton was receiving the recipient of dates of) his (son), distinguished in all his relics, Horus who rejuvenates the spirits of his father and keeps his body alive in the castle of gold'(121). Isis says: 'words are spoken by Isis, the life mistress of Abaton the djedyt in Philae'. As for Harendoutes, his accompanying texts say: 'words are spoken by Harendoutes the great master god of the Abaton the venerable effigy of Philae, ${ }^{(122)}$.

Tiberius is depicted wearing the Blue Crown<smiles>C1CCC2CCCC2C1</smiles>
as well as the Double Feather Crown majority of dates' offering scenes, Osiris is represented wearing his Atef Crown crowned with the Hathouric crown and the hieroglyphic sign of her name $\sqrt{6}$. God Harendotus is depicted as a falcon headed deity wearing the Double Crown . The three deities are depicted seated on the throne and holding the $n_{h}$ sign with their left hands and the $w 3 s$ scepter $h$ with their right hands except goddess Isis who holds the $w \underline{3} \underline{d}$ sign $\int$ with her right hand.

2.2.3. Scenes of Palm Dates Offerings to Osiris, Isis, Harendotus, and Thoth of Pnubis:

The four deities are Osiris, Isis, Harendotus and Thoth of Pnubis. The scene is found on the wall of western colonnade of Philae temple ${ }^{(123)}$, upper register, $11^{\text {th }}$ scene (fig. 8) ${ }^{(124)}$. It depicts the Roman Emperor Tiberius (14 A.D.-37 A.D.) presenting palm dates to Osiris, Isis, Harendotus and Thoth of Pnubis. ${ }^{125}$ The scene is titled;

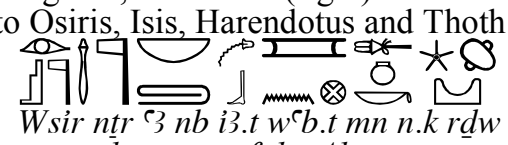

'Osiris, the great god master of the Abaton, accepts the outflow

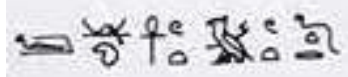

pri im.k 'nh ti m3wi.ti d.t

that comes from you so that you may live and renew you ${ }^{,(127)}$.

The Roman emperor Tiberius says: 'King of Upper and Lower Egypt the Autocrat, on his throne, excellent sovereign beloved of both, is offering the vessels of dates to his master, to appease his heart with his spirits, the son of Isis who rejuvenated his father in the temples of Upper and Lower Egypt'. ${ }^{28}$ Osiris says; 'receiving the vessels of dates of his distinguished son in all his relics, it is as (Horus who rejuvenates) the spirits of his father and makes his body live in the castle of gold'. ${ }^{12}$ Goddess Isis says: 'words are spoken by Isis gifted with life mistress of the Abaton mistress of Philae who protected her brother in the cities and the nomes and makes his majesty alive (in) the divine temples'.Harendotes says: 'words are spoken by Harendotes ... master of the Abaton who is protected in the two sanctuaries'. Finally, Thoth of Pnubs says: ' words are spoken by Thot of Pnubis, the great god master of Philae ..., the southern lion, ${ }^{,(130)}$.

The Roman emperor is depicted wearing the blue crown and the double feather crown . Concerning god Osiris, he is depicted with his traditional Atef Crown sun disc between two horns, with the hieroglyphic sign of her name $]$. God Harendotus is depicted as a falcon headed man wearing the Double Crown . Finally, Thoth of Pnubis is represented as a male deity wearing four feathers over his head.

\section{Scenes of Offering Palm Dates to Horus and Apis:}

In the temple of Edfu, Horus the Great, the main god of the temple, replaced his father in receiving this type of Osirian offerings ${ }^{(131)}$. In this scene, Horus is accompanied with god Apis who is depicted as a bull headed man. 
Despite the absence of accompanying text in the latter temple, the pyramidal shape of the depicted offering confirms its identification as offering the vessel of palm dates ${ }^{(132)}$. This scene is located on the northern wall of the Hall of Offerings (R), first register, first scene (fig.9) ${ }^{(133)}$. King Ptolemy IV Philopator (221 B.C-204 B.C) is represented offering palm dates to both Horus of Edfu and Apis. The scene is titled as: $b n q^{(134)}$. Moreover, part of the text accompanying the depicted king describes the whole scene with the following words;

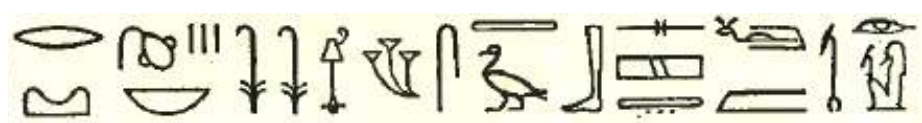

$r \underline{d} w$ snw gb š̌t 3 pri $m$ wsir

'All the essence arising from Geb the emanations of Osiris ${ }^{\text {(135) }}$

The Ptolemaic king is depicted standing and crowned with a composite crown crown and a double feather crown. Apis and Horus are standing and facing each other. Apis is depicted as a bull headed man. Concerning god Horus, he is a represented as falcon headed man and crowned with the Double Crown . He holds the $w 3$ s scepter $h$ in his right hand and the ${ }^{2} n h$ sign $f$ in his left hand. This scene shows a striking iconography where the two depicted deities, Apis and Horus are facing each other. Unlike the other scenes of date offerings, Apis is depicted in a standing position and depicted side by side with the Ptolemaic king. God Apis is standing towards an offering table. The accompanying text describes this deity as (136).

\section{Scenes of Offering Palm Dates to Ptah:}

In the temple of Tod, the ritual of offering Palm dates is also depicted on the top of the southern doorpost giving access to the Offering Hall (C) fourth register. This shows Ptolemy VIII Eurgetes II (169 B.C.-116 B.C.)

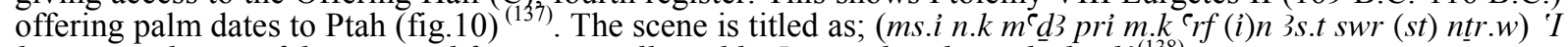
bring you the jar of dates issued from you, collected by Isis so that the gods drink ${ }^{(138)}$.

The Ptolemaic king says; 'I give you all the plants ( $r \underline{d} w)$ that are on the back of Geb'. The accompanying text of the mummified god Ptah says: "Words are spoken by Ptah with the perfect face, who resides in Thebes, the great god who resides in Tod, ${ }^{(139)}$. The Ptolemaic king is depicted in a standing positions and wearing the nemes headdress, two horns, and the Double Crown . As for god Ptah, he is depicted as a mummified man wearing his skull cap and holding the $w 3 s$ scepter $h$ with his both hands.

\section{Scenes of Offering Palm Dates to Shu and Tefnut:}

In the Temple of Qal'a, mainly on the façade of the central sanctuary, northern wall, second register, both Shu and Tefnut are depicted receiving jars of palm dates from the Roman emperor Augustus (27 B.C- 14 AD) ${ }^{(140)}$. Despite the absence of accompanying text in the latter temple, the pyramidal shape of the depicted offering confirms its identification as palm dates (fig.11) ${ }^{(141)}$. The king is depicted in the standing position, crowned with a composite crown, and offering palm dates to both Shu and Tefnut. This composite crown consists of the Red Crown of Lower Egypt and the Atef Crown . God Shu is figured crowned with a šw sign over his head and seated on the throne. He holds the $w 3 s$ scepter $h$ in the left hand and the ${ }^{\prime} n h$ sig $f$ in the other hand. Goddess Tefnut is depicted as a standing lioness headed deity before Shu and crowned with the sun disc over head. She holds the $w^{3} \underline{d} \operatorname{sign} \int_{\text {in her left hand and the }{ }^{n} h \operatorname{sig}}$ in the other hand. The accompanying text head. She holds the $w 3 \underline{d}$ sign in her left hand and the $n h$ sig in the other hand. The accompanying text reveal's only traces of the name of Augustus names of god Shu $P$ and Tefnut 2 .

\section{Results:}

According to table no.1, certain points could be concluded in the topic in question;

6.1. Elven scenes represent the ritual of offering palm dates to the Egyptian deities in the temple. Six scenes date back to the Ptolemaic period (scene no. 1,2,3,4,9, and 10). The oldest scene dates back to the reign of Ptolemy IV Philopator (221 B.C-204 B.C) in the temple of Edfu (scene no.9). Ptolemy VIII Eurgetes II (169 B.C.-116 B.C.) was the most common Ptolemaic king being depicted offering palm dates to the deities. His figure appeared in three scenes; two in Edfu temple (scene no. 1, and 2) and one in the temple of Tod (scene no.10). On the other hand, five scenes date back to the Roman era (scene no. 5,6,7,8, and 11). Three scenes out of five belong to the Roman Emperor Augustus (27 B.C- 14 AD). The three scenes of Augustus are located in three different temples; one in Denderah temple (scene no.5), one in the temple of Philae (scene no.6) and the last scene is found in the temple of Qal'a (scene no. 11). The Roman emperor Tiberius (14 A.D.-37 A.D.) was 
depicted offering palm dates twice in the temple of Philae (scene no. 7, 8). After the reign of this emperor, scenes of offering palm dates were no more attested in the temples of Egypt.

6.2. Based on their connection with the Osirian cult, other deities began to share Osiris in receiving this kind of offerings; a new tradition that appeared in the Egyptian temples as early as the Roman period. Thus, it seems that the Egyptian priests became more flexible in depicting other deities led by Osiris to receive vessels of palm dates. However the Osirian context of this offering maintained to be clearly expressed through the accompanying textual context. Mainly Isis, Thoth of Pnubis, and Harendotus shared Osiris in receiving palm dates from the Roman emperor. However, other deities replaced Osiris himself in such scenes since the Ptolemaic period. These deities are Apis and Horus the Great in Edfu temple (scene no. 9), Ptah in the temple of Tod (scene no. 10 ), and Shu and Tefnut in El-Qal'a temple (scene no. 11).

\subsection{The deities which were depicted receiving this kind of offering in the Egyptian temples are;}

6.3.1. Osiris: his image dominated the majority of scene's of dates offering. He was either depicted alone in four scenes (scene no.1,2,3,4) or being accompanied with other deities. Osiris was depicted side by side with his consort Isis in two scenes (scene no. 5,6). The two deities were depicted with god Harendotus in one scene in Philae temple (scene no. 7). Only one scene depicts three deities, namely Isis, Harendotus, and Thoth of Pnubis, receiving palm dates with god Osiris (scene no. 8). In addition, Osiris bore the title 'Osiris Khentimenti' once in the temple of Edfu (scene no.2). The deity was named 'Osiris Wennefer' three times; in the temple of Edfu (scene no.1), and in two scenes in Dendara temple, mainly in the chamber of Sokar (scene no. 3, 4). Osiris was also identified with god Sokar and appeared as a falcon headed deity receiving palm dates in the temple of Isis as Philae (scene no.6).

The Osirian title Wennefer, which was the origin of the Greek rendering of god Onnophris, is translated as 'he who is everlasting good condition'. By this way, the title reflects triumph of the deity over death ${ }^{(142)}$; a concept that integrates with the symbolism of palm dates in rejuvenating the body of Osiris. Wennefer was one of the titles of god Osiris which were usually mentioned in the Book of the Dead. Chapter 17 describes Osiris Wennefer as a provider of food for the deceased as follows; 'Here begin praises and recitations, going in and out of the God's Domain, having benefit in the beautiful West, being suite of Osiris, resting at the food-table of Wennefer' ${ }^{(143)}$. Thus, Osiris bore the title Wennefer in the scenes of dates offering in order to reveal his function as a provider of food, including palm dates, in the Otherworld.

Concerning the title Khenti Menti or namely 'the Foremost of the West', it is one of the basic epithets of Osiris revealing his function as a god of the Otherworld ${ }^{(144)}$. In addition, based on their funerary function, Osiris was identified with god Sokar. The character of god Sokar, which became one of the aspects of Osiris, was highly influenced by the Osirian myth and festivals ${ }^{(45)}$. Both Osiris Khenti-Menti and Osiris Sokar ${ }^{(146)}$ were two basic forms of Osiris that were pictorially represented on the walls of Denderah temple. The scenes and inscriptions of the temple describe manufacturing the figures of Osiris Khenti-Amnety and Osiris Sokar among the Khoaik celebrations in which offering of palm dates was involved ${ }^{(147)}$. On the other hand, dates are used in making the molds of Sokaris. In the rituals of these ceremonies, Osiris was regenerated by the rays of Re turning him to an infernal sun 'he enlightens those who are in the Nun, ${ }^{\text {(148). }}$

6.3.2. Isis: This deity was always depicted receiving palm dates with her husband. Thus, offering palm dates to Isis is rather based on her connection with Osiris and her role in reuniting his body. The accompanying texts of this goddess describe her mythical role in the resurrection of Osiris.

In scene no. 5 in the temple of Dendarah and scene no. 6 in Philae temple, Isis bore the title 'Isis Shentayt'. Moreover, Ptolemy VIII bore the title 'son of Shentayt' in scene no. 1. In Edfu temple. This tradition continued daring the Roman period. In Denderah temple, the Roman emperor Augustus was also named 'son of Shentayt' (scene no.5) ${ }^{(149)}$. One of her forms is called Isis the widow 'Isis Shentayt'. derived from šn.w was particularly venerated in Busuris. Together with Merkethes, one of the forms of goddess Hathour, Shentayt played a crucial role in the Osirian cult. In addition, this deity was described to be responsible for making the socalled Osiris beds ${ }^{(152)}$. In the scenes of offering palm dates, Isis Shentayt was repeatedly mentioned as the one responsible for 'reuniting of the body' referring to the body of her consort Osiris (153). In the temple of Denderah, the rejuvenation of Osiris was carried out by Isis in a place called 'the Golden Castle'. Isis, in the form of Shentayt, was named the 'coming one who presided over the reconstitution of the divine body'. The mystery of Denderah accurately designated the place where this operation was carried out by the expression $p r$ $\check{s} n t^{\ulcorner} y t$. The word $s 3 s^{3} t 3 y t$ in both Edfu and Denderah temples evokes the rites of Khoaik festival of Osiris ${ }^{(154)}$.

Isis was depicted receiving palm dates with Osiris in four scenes (scene no. 5, 6, 7, and 8). They were depicted in two scenes; one in the temple of Denderah (scene no.5) and the other in the temple of Philae (scene no. 6). In this scene, Isis Shentayt appeared side by side with Osiris Sokar. The two deities were strongly related since Sokar was named 'lord of Shentayt Shrine, ${ }^{(155)}$. In other cases, the divine couple accompanied Harendotus in the temple of Philae (scene no. 7) and with Harendotus and Thoth of Pnubis in the same temple (scene no. 8).

6.3.3. Horus: three scenes represent Horus receiving palm dates in the temples of Egypt (scene no. 7, 8, and 9). In scenes no, 8 and 9 in the temple of Philae, Horus appeared in the form of Harendotus who owned his special temple ${ }^{(156)}$. He was depicted side by side with Isis and Osiris. The latter god (Greek: A $9 \varepsilon v d \omega \tau \eta \varsigma^{(157)}$, $A \rho \varepsilon v \delta \omega \tau \tau \eta \varsigma^{(158)}$ is the Greek rendering of the Egyptian god $h r-n \underline{d}(t i)$ it.f or $h r-n \underline{d}(t i)-h r . i t . f^{(159)}$. His name is translated 'Horus the savior, the revenge, the champion of his father' ${ }^{160}$. The name hr nd itf 
was also translated as 'the assistant of his father ${ }^{,(161)}$ The word $n \underline{d i}{ }^{(162)}$ is rather translated as 'taking care of', showing piety towards, ${ }^{\text {(163) }}$.

Harendotus connection with his father Osiris was obviously the main reason behind accompanying him in receiving palm dates. The name of this deity reflects its dual function being responsible for his father's duty ${ }^{(164)}$. Furthermore, he played a funerary role in restoring the physical power and body of Osiris to achieve the latter's resurrection ${ }^{(165)}$. The role of Harendotus was mentioned in the Pyramid Texts ${ }^{(166)}$. In spell 562, he was described as the royal successor of his father ${ }^{(167)}$. Part of the spell says; 'govern the gods as a king, as the representative of Horus who protects his father Osiris ${ }^{,(168)}$. Other spells describe the role of Harendotus as the protector of the dead $^{(169)}$. For instance, part of spell 468 of the Pyramid Texts says; 'Horus who protects his father Osiris, The son has protected his father. Horus has protected this king, ${ }^{(170)}$. Furthermore, the role of this deity was mentioned in the Coffin Texts ${ }^{(171)}$. For instance, in spell 46 of the Coffin Texts, the deceased king was identified with Harendotus as follows; 'when they see you coming crowned as Horus, Protector of his father, the offspring of his father Osiris ${ }^{(172)}$. In addition, Horus appeared alone without the presence of his father Osiris in scene no. 9 in Edfu temple. Horus, who appeared in this scene in the form of Horus the Great as a falcon headed deity, seems to have replaced the role of his father in the ritual of palm dates offering.

6.3.4. Thoth of Pnubis: this deity was depicted in a solemn scene in Philae temple receiving palm dates (scene no. 8). This Nubian god took the iconography of a lion and shared the name of Thoth of Hermopolis. Furthermore, Thoth of Pnubis shared all the characters of Onuris, Arsenophis, and god Shu. In the temple of Philae, Thoth of Pnubis is titled 'lion of the south, mighty in strength'(173). In fact, some scholars found a similarity between palm dates which began to be connected with the cult of Thoth. These dates were described to be his preferred meal. Thus, numerous scenes form the Thebean tombs represent the apes of Thoth sitting on the table of their master and eating palm dates ${ }^{(174)}$. The apes of god Thoth were even represented assisting in colleting palm dates during harvest ${ }^{(175)}$. Scarabs from the Late Period depict two and frequently four apes standing flanking a palm and holding its stem $^{(176)}$. The palm tree was interpreted by Harapollon to be a representative for the year since the depicted tree has twelve branches referring to the twelve months of the year. Therefore, this scene was translated nfr rnp.t a reflecting the hope of a good coming years ${ }^{(177)}$.

6.3.5. Apis: was depicted in scene no. 9 with god Horus of Edfu receiving palm dates in the temple of Edfu. In this scene, Apis was named 'herald of Ptah' revealing his function as the incarnation or the soul of god Ptah to whom palm dates were also offered ${ }^{(178)}$. The relation between palm dates and the bull cult was attested in Egypt as early as the Pharaonic period. Part of spell 403 of the Pyramid Texts says; ' O you Bulls of Atum, make the King sturdy, strengthen (?) the King more than the Nt-crown which is on him, more than the flood which is on his lap, more than the dates which are in the fist ${ }^{\text {(179) }}$. Thus, Apis who was usually linked with the kingship of Egypt symbolized the physical strength of the king of Egypt as early as the Pharaonic period. Among the HebSed rituals, the bull of Apis shared in the celebration to rejuvenate the strength of the Pharaoh. By this way, Apis was connected with the cult of Osiris, who symbolized the king after the death ${ }^{(180)}$.

6.3.6. Ptah: is depicted in the oldest scene of dates offering in the temple of Tod in front of Ptolemy IV (scene no. 10). In the temple of Tod, the Osirian origin of the offering is clearly marked in the mythological contexts of the temple. The mention of Isis and the plants/essence of Geb confirm the Osirian identity of this offering. However, Montu's priests adapted this Osirian offering and placed it in a different context. Unlike the scenes of Edfu, where this oblation was consecrated to Osiris, Ptah, one of the secondary deities of Tod temple, received here one of the containers of palm dates ${ }^{(181)}$.

6.3.7. Shu and Tefnut: are depicted together receiving palm dates from the Roman emperor Augustus in Edfu temple (scene no. 11). It is a remarkable scene of palm date offering for several reasons. It is the solemn scene for offering this type of oblations to Shu and Tefnut. Unlike all other scenes which represent more than one deity, Shu and Tefnut here are not symmetrically shown in this iconography. While Shu is depicted seated on the throne, his consort Tefnut is depicted in a standing position as an animal headed human.

Dates which were described to be flowers of $\mathrm{Re}^{(182)}$ were presented to this kind of deities that were connected to the concept of renewal and resurrection in ancient Egypt. Furthermore, the two deities enjoyed a certain solar character. Tefnut was described to be the 'Eye of $R e^{\text {,(183) }}$. As for Shu, he was described to dwell in the sun disc ${ }^{(184)}$. In ancient Egyptian art ${ }^{(185)}$, the two deities were represented in the form of two kneeling lions symbolizing the two horizons of yesterday and tomorrow ${ }^{(186)}$. In scene no. 2 in Edfu temple, Ptolemy VIII was described to be 'the steward of Shu fields'. This title appeared describing the Roman emperor Augustus also in scene no. 5 in Denderah temple. The epithet clearly reveals the funerary aspect of this ritual ${ }^{(187)}$.

6.4. Scenes of palm dates offerings are located in five temples. Three scenes are found in Edfu temple (scenes no. 1, 2, and 9), three other scenes are found in Denderah temple (scenes no 3, 4, and 5), and three in the temple of Philae (scenes no. 6, 7, and 8). One scene is located in the temple of El-Tod (scene no.10), and the last scene is in the temple of El-Qal'a (scene no.11).

\subsection{The location of these offering scenes provides further guidance to their religious symbolism and importance:}

6.5.1. In some cases, offering palm dates was ichnographically represented in the inner parts of the temple revealing its sacred symbolism especially during the Ptolemaic period. For example, two scenes are located in the chapel of Sokar at Denderah (scene no. 3 and 4) and are dedicated to Osiris. Being a chamber consecrated for the necessary rituals for the regeneration of Osiris at the beginning of the year, this location confirms the 
regenerative character of the dates ${ }^{(188)}$. Moreover, this offering was also represented once in the sanctuaries of the temples. It is found in the central sanctuary of Qal'a temple (scene no.11).

6.5.2. In other cases, offering palm dates was depicted on the outer parts of the temples. Four scenes are located on the exterior wall of the naos; two of them are located in Edfu temple (scene no. 1 and 2) and one scene in Denderah temple (scene no. 5) and another scene in the temple of Isis at Philae (scene no. 6). This privileged location was explained by Derchain to reveal the ritualistic function of this type of offerings ${ }^{(189)}$. Offering palm dates was also found twice in the Hall of Offerings of the Egyptian temples; one in the temple of Edfu (scene no.9) and in the temple of Tod (scene no. 10). This location confirms that offering palm dates became a ritual that was attended by the crowds of the temples. In other words, offering dates changed from being a sacred ritual in the Ptolemaic era to be more a common ritual in the late Ptolemaic and Roman period. This cultic change is obviously attested in the temple of Isis at Philae where two scenes are strikingly located in the outer parts of the main temple. The first scene is located in the western colonnade of the temple (scene no. 8) and the other in the second eastern colonnade of the temple (scene no.7).

6.5.3. The king is always depicted in the previous scenes wearing his ceremonial tail and kilt. He was depicted wearing the Double Crown (scene no. 3,4, and accompanied with two horns and the nemes headdress in scene no. 10), the Red Crown of Lower Egypt

scene no. 10), the Red Crown of Lower Egypt (scene no. 1), being sometimes composite with the Atef Crown (scene no. 6, and 11), the White Crown of Upper Egypt 5), and a composite crown 5), and a composite crown (scene no.9). In the two scenes of Tiberius (scene depicted crowned with the blue crown

6.6. Concerning the shape of the palm dates. It takes the cuboid shape resembling the shape of the naos with a conical cover. According to the scenes of dates offerings, this naos-shaped container was topped with a small pyramidion ${ }^{(190)}$ recalling the shape of the Heliopolitan $b_{n b n}{ }^{(191)}$. The expression $b 3 w$ iwnwn should thus be explained by this solar and Heliopoliatn aspect of Osiris ${ }^{(192)}$. In some cases, the cover of the jar was not depicted (scene no. 10). In one example, the cover takes a sloping shape instead of the conical cover (scene no.6) Some scholars find similarity between the shape of the basket of dates (a kind of small naos) and with the necklace oudja, without the collar itself. However, according to Ch. Thiers, the Osirian context of dates' offerings is sufficient to refuse such a hypothesis. Thiers rather believes that this Osirian ritual began to be represented and accepted by other deities ${ }^{(193)}$. It should be noticed that this slope-shaped cover looks like the hieroglyphic sign

Peing originally an Osirian ritual, the relation between this shape of dates containers and the name of god Osiris $\overbrace{}^{(194)}$ is possible. This shape of vases might evoke the name of god Osiris to whom this type of offerings was specially consecrated for.

Table (1) Compares between the eleven scenes of presenting palm dates in the Egyptian temples during the Græco-Roman Period

\begin{tabular}{|c|c|c|c|c|c|c|c|}
\hline Scene & King & Deities & Crowns & Emblems & $\begin{array}{l}\text { Shape of the } \\
\text { Dates' Jug }\end{array}$ & Location & Period \\
\hline $\begin{array}{c}\text { Scene no. } \\
1\end{array}$ & $\begin{array}{c}\text { Ptolemy VIII } \\
\text { Eurgetes II (169 B.C.- } \\
116 \text { B.C.) }\end{array}$ & $\begin{array}{l}\text { Osiris Wennefer } \\
\text { (seated position) }\end{array}$ & $\begin{array}{l}\text { Ptolemy VIII: } \\
\text { Red Crown of Lower } \\
\text { Egypt } \\
\text { Osiris Wennefer: } \\
\text { composite Crown (Andjet } \\
\text { Crown) }\end{array}$ & Osiris: 'nh sign & $\begin{array}{l}\text { Cuboid body } \\
\text { container and } \\
\text { conical cover }\end{array}$ & $\begin{array}{l}\text { exterior western } \\
\text { wall of naos, fourth } \\
\text { register, second } \\
\text { scene } \\
\text { Edfu Temple }\end{array}$ & $\begin{array}{l}\text { Ptolemaic } \\
\text { Period }\end{array}$ \\
\hline $\begin{array}{l}\text { Scene } \\
\text { no. } 2\end{array}$ & $\begin{array}{c}\text { Ptolemy VIII } \\
\text { Eurgetes II (169 B.C.- } \\
116 \text { B.C.) }\end{array}$ & $\begin{array}{c}\text { Osiris } \\
\text { Khentimenti } \\
\text { (seated position) }\end{array}$ & $\begin{array}{l}\text { Ptolemy VIII: White } \\
\text { Crown of Lower Egypt } \\
\text { Osiris Khentimenti: Atef } \\
\text { Crown }\end{array}$ & 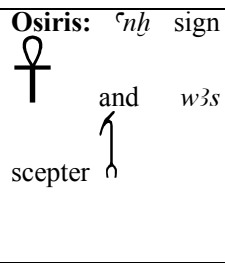 & $\begin{array}{l}\text { Cuboid body } \\
\text { container and } \\
\text { conical cover }\end{array}$ & $\begin{array}{c}\text { exterior eastern wall } \\
\text { of naos, fourth } \\
\text { register, second } \\
\text { scene } \\
\text { Edfu Temple }\end{array}$ & $\begin{array}{l}\text { Ptolemaic } \\
\text { Period }\end{array}$ \\
\hline $\begin{array}{l}\text { Scene } \\
\text { no. } 3\end{array}$ & $\begin{array}{l}\text { Ptolemaic King } \\
\text { (unidentified, } \\
\text { belonging to the late } \\
\text { Ptolemaic period) }\end{array}$ & $\begin{array}{l}\text { Osiris Wennenefer } \\
\text { (standing position) }\end{array}$ & $\begin{array}{l}\text { Ptolemaic King: Double } \\
\text { Crown of Upper and } \\
\text { Lower Egypt } \\
\text { Osiris Wennenefer: Atef }\end{array}$ & 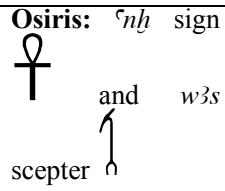 & $\begin{array}{l}\text { Cuboid body } \\
\text { container and } \\
\text { conical cover }\end{array}$ & $\begin{array}{c}\text { northern wall of the } \\
\text { third eastern } \\
\text { chamber (F) (Hall of } \\
\text { Sokar), first register, } \\
\text { third scene, } \\
\text { Denderah Temple }\end{array}$ & $\begin{array}{l}\text { Ptolemaic } \\
\text { Period }\end{array}$ \\
\hline
\end{tabular}




\begin{tabular}{|c|c|c|c|c|c|c|c|}
\hline & & & Crown & & & & \\
\hline $\begin{array}{c}\text { Scene } \\
\text { no. } 4\end{array}$ & $\begin{array}{l}\text { Ptolemaic King } \\
\text { (unidentified, } \\
\text { belonging to the late } \\
\text { Ptolemaic period) }\end{array}$ & $\begin{array}{l}\text { Osiris Wennenefer } \\
\text { (standing position) }\end{array}$ & $\begin{array}{l}\text { Ptolemaic King: Double } \\
\text { Crown of Upper and } \\
\text { Lower Egypt } \\
\text { Osiris Wennenefer: Atef } \\
\text { Crown }\end{array}$ & 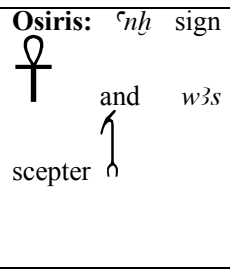 & $\begin{array}{l}\text { Cuboid body } \\
\text { container and } \\
\text { conical cover }\end{array}$ & $\begin{array}{l}\text { southern wall of the } \\
\text { third eastern } \\
\text { chamber (F) (Hall of } \\
\text { Sokar), first register, } \\
\text { third scene, } \\
\text { Denderah Temple }\end{array}$ & $\begin{array}{l}\text { Ptolemaic } \\
\text { Period }\end{array}$ \\
\hline $\begin{array}{c}\text { Scene } \\
\text { no. } 5\end{array}$ & $\begin{array}{c}\text { Roman emperor } \\
\text { Augustus (27 B.C- } 14 \\
\text { AD) }\end{array}$ & $\begin{array}{l}\text { Osiris and Isis } \\
\text { Shentayt (seated } \\
\text { position) }\end{array}$ & $\begin{array}{l}\text { Augustus: } \\
\text { The Atef Crown } \\
\text { Osiris: the Andjeti Crown } \\
\text { Isis Shentayt: Hathouric } \\
\text { crown. }\end{array}$ & $\begin{array}{l}\text { Osiris: the 'nh } \\
\text { sign } \\
\text { Isis: the } n h \text { and the sign } \\
\text { sign. }\end{array}$ & $\begin{array}{l}\text { Cuboid body } \\
\text { container and } \\
\text { conical cover }\end{array}$ & $\begin{array}{l}\text { the exterior western } \\
\text { wall of the naos }(\mathrm{H}) \text {, } \\
\text { fourth register, } \\
\text { thirteenth scene, } \\
\text { Denderah Temple }\end{array}$ & Roman Period \\
\hline $\begin{array}{c}\text { Scene } \\
\text { no. } 6\end{array}$ & $\begin{array}{c}\text { Roman emperor } \\
\text { Augustus (27 B.C- } 14 \\
\text { AD) }\end{array}$ & $\begin{array}{c}\text { Osiris Sokar } \\
\text { (falcon headed } \\
\text { deity, seated } \\
\text { position) and Isis } \\
\text { Shentayt (seated } \\
\text { position) }\end{array}$ & $\begin{array}{l}\text { Augustus: } \\
\text { composite crown } \\
\text { consisting of the Red } \\
\text { Crown of Lower Egypt } \\
\text { Isis Shentayt: Hathouric } \\
\text { crown and the hieroglyphic } \\
\text { headed) Atef Crown } \\
\text { sign of her name st } \text {. Sokar: }\end{array}$ & $\begin{array}{l}\text { Osiris: the } \\
n h h \text { sign } \\
\text { and } w 3 s \text { scepter } \\
\text { Isis }\end{array}$ & $\begin{array}{l}\text { Cuboid body } \\
\text { container and } \\
\text { slope- shaped } \\
\text { cover }\end{array}$ & $\begin{array}{l}\text { exterior western wall } \\
\text { of the naos, second } \\
\text { register, fourth } \\
\text { scene, Temple of Isis } \\
\text { at Philae }\end{array}$ & Roman Period \\
\hline $\begin{array}{c}\text { Scene } \\
\text { no.7 }\end{array}$ & $\begin{array}{c}\text { Roman emperor } \\
\text { Tiberius (14 A.D.-37 } \\
\text { A.D.) }\end{array}$ & $\begin{array}{l}\text { Osiris (seated } \\
\text { position) } \\
\text { Isis (seated } \\
\text { position) } \\
\text { Harendotes } \\
\text { (seated falcon } \\
\text { headed deity) }\end{array}$ & $\begin{array}{l}\text { Tiberius: the blue crown } \\
\text { feather crown } \\
\text { Osiris: } \\
\text { the his: hathouric crown, with } \\
\text { her name Crown } \\
\text { harendotus: } \\
\text { headed man) wearing the } \\
\text { Double Crown sign of }\end{array}$ & Osiris: : 'nh sign & $\begin{array}{l}\text { Cuboid body } \\
\text { container and } \\
\text { conical cover }\end{array}$ & $\begin{array}{c}\text { The second eastern } \\
\text { colonnade, hall of } \\
\text { Tiberius, south wall, } \\
\text { upper register, } \\
\text { Temple of Isis at } \\
\text { Philae }\end{array}$ & $\begin{array}{l}\text { The Roman } \\
\text { Period }\end{array}$ \\
\hline $\begin{array}{c}\text { Scene } \\
\text { no. } 8\end{array}$ & $\begin{array}{c}\text { Roman emperor } \\
\text { Tiberius (14 A.D.-37 } \\
\text { A.D.) }\end{array}$ & $\begin{array}{l}\text { Osiris, } \\
\text { Isis, Harendotus } \\
\text { (falcon headed } \\
\text { deity) and Thoth } \\
\text { of Pnubis }\end{array}$ & $\begin{array}{l}\text { Tiberius: the blue crown } \\
\text { feather crown } \\
\text { Osiris: } \\
\text { Isis: hathouric crown, with } \\
\text { her name hieroglyphic sign of } \\
\text { Harendotus: }\end{array}$ & & $\begin{array}{l}\text { Cuboid body } \\
\text { container and } \\
\text { conical cover }\end{array}$ & $\begin{array}{l}\text { wall of western } \\
\text { colonnade of Philae } \\
\text { temple, upper } \\
\text { register } 11^{\text {th }} \text { scene, } \\
\text { Temple of Isis at } \\
\text { Philae }\end{array}$ & Roman Period \\
\hline
\end{tabular}




\begin{tabular}{|c|c|c|c|c|c|c|c|}
\hline & & & $\begin{array}{l}\text { headed man) wearing the } \\
\text { double crown } \\
\text { Thoth of Pnubis: wearing } \\
\text { four feathers over his head. }\end{array}$ & & & & \\
\hline $\begin{array}{l}\text { Scene } \\
\text { no. } 9\end{array}$ & $\begin{array}{c}\text { King Ptolemy IV } \\
\text { Philopator (221 B.C- } \\
204 \text { B.C) }\end{array}$ & $\begin{array}{c}\text { Horus the Great } \\
\text { (standing falcon } \\
\text { headed deity) } \\
\text { Apis (standing } \\
\text { bull headed deity) }\end{array}$ & $\begin{array}{l}\text { Ptolemy IV Philopator: a } \\
\text { composite crown } \\
\text { ( flat crown and a double } \\
\text { feather crown). } \\
\text { Apis: (bull headed man). } \\
\text { Horus of Edfu: (falcon } \\
\text { headed man): crowned } \\
\text { with the Double Crown } \\
\text { yy }\end{array}$ & $\begin{array}{l}\text { Horus the Great: } \\
\text { the w3s scepter } \\
\text { and the } n h \text { sign } \\
\text {. }\end{array}$ & $\begin{array}{l}\text { Cuboid body } \\
\text { container and } \\
\text { conical cover }\end{array}$ & $\begin{array}{l}\text { The northern wall of } \\
\text { the hall of offerings } \\
\text { (R), first register, } \\
\text { first scene, Edfu } \\
\text { Temple }\end{array}$ & $\begin{array}{c}\text { The Ptolemaic } \\
\text { Period }\end{array}$ \\
\hline $\begin{array}{l}\text { Scene } \\
\text { no.10 }\end{array}$ & $\begin{array}{c}\text { Ptolemy VIII } \\
\text { Eurgetes II (169 B.C.- } \\
116 \text { B.C.) }\end{array}$ & $\begin{array}{l}\text { Ptah (standing } \\
\text { position) }\end{array}$ & $\begin{array}{l}\text { Ptolemy VII Eurergetes } \\
\text { II: the nemes headdress, } \\
\text { two horns, and the Double } \\
\text { Crown } \\
\text { Ptah: skull cap }\end{array}$ & Ptah: $\mathfrak{r}^{\text {the }}$ w3s & $\begin{array}{l}\text { Cuboid body } \\
\text { container }\end{array}$ & $\begin{array}{l}\text { The southern } \\
\text { doorpost giving } \\
\text { access to the } \\
\text { Offering Hall (C), } \\
\text { fourth register, } \\
\text { El-Tod Temple }\end{array}$ & $\begin{array}{l}\text { The Ptolemaic } \\
\text { Period }\end{array}$ \\
\hline $\begin{array}{l}\text { Scene } \\
\text { no.11 }\end{array}$ & $\begin{array}{c}\text { Augustus (27 B.C- } 14 \\
\text { AD) }\end{array}$ & $\begin{array}{l}\text { Shu (seated) and } \\
\text { Tefnut (standing) }\end{array}$ & $\begin{array}{l}\text { Augustus: } \\
\text { crown (Red Crown of } \\
\text { Lower Egypt and the }\end{array}$ & $\begin{array}{l}\text { Shu: } \\
\text { with a šw the } \\
\text { sign over his head. } \\
\text { He holds the } w 3 s \\
\text { scepter in the } \\
\text { left hand and the } \\
\text { 'nh sig in the } \\
\text { other hand. } \\
\text { Tefnut: } \\
\text { lioness headed } \\
\text { deity, crowned } \\
\text { with the sun } \\
\text { disc } \\
\text { head. } \\
\text { holds the } w 3 \text { over } \\
\text { sign in her } \\
\text { left hand and } \\
\text { the the ' } n h \text { sig } \\
f \\
\text { hand. } \\
\text { han other }\end{array}$ & $\begin{array}{l}\text { Cuboid body } \\
\text { container and } \\
\text { conical cover }\end{array}$ & $\begin{array}{l}\text { The façade of the } \\
\text { central sanctuary, } \\
\text { northern wall, second } \\
\text { register, } \\
\text { Temple of Qal'a, }\end{array}$ & $\begin{array}{l}\text { The Roman } \\
\text { Period }\end{array}$ \\
\hline
\end{tabular}

\section{مناظر تقدمة بلح النخيل في المعابد المصرية خلال العصرين اليوناني والروماني سارة السيد كتات}

تعد مناظر تقديم بلح النخيل من المناظر الهامة المصورة في المعابد المصرية خلال العصر اليوناني- الروماني. وبوجد إحدى عشر منظرا يصور من خلالهم الملك البطلمي أو الإمبراطور الروماني وهو يقدم البلح إلى الآلهة. وقد أنتهى تصوير هذه التقدمة في المعابد مع عصر الإمبراطور تراجان. وكانت تقدمة بلح النخيل من التقدمات المقدسة للإله أزوريس خلال إحتفالات كهيك، وهذا يفسر ظهور شكل هذا المعبود في أغلب المناظر. وقد أرتبط تقديم البلح للمعبودة إيزيس بدورها في إعادة تجميع جسد أزوريس. وفي أقدم منظر لتقدمة بلح النخيل والمصور في معبد أدفو ، نجد الملك بطلميوس الرابع وهو يقدم بلح النخيل لكلا من أبيس وحور. وقد صور حارندوتس وهو يستقبل البلح في منظرين بمعبد فيلة. كما صور تحوت بنوبيس في منظر وحيد لتقدة البلح في معبد فيلة. وقد صور تحوت وهو يستقبل البلح في معبد

$$
\text { الطود. كما صور الإمبرطدور أغسطس وهو يقدم البلح لشو وتفنوت في معبد القلعة. }
$$




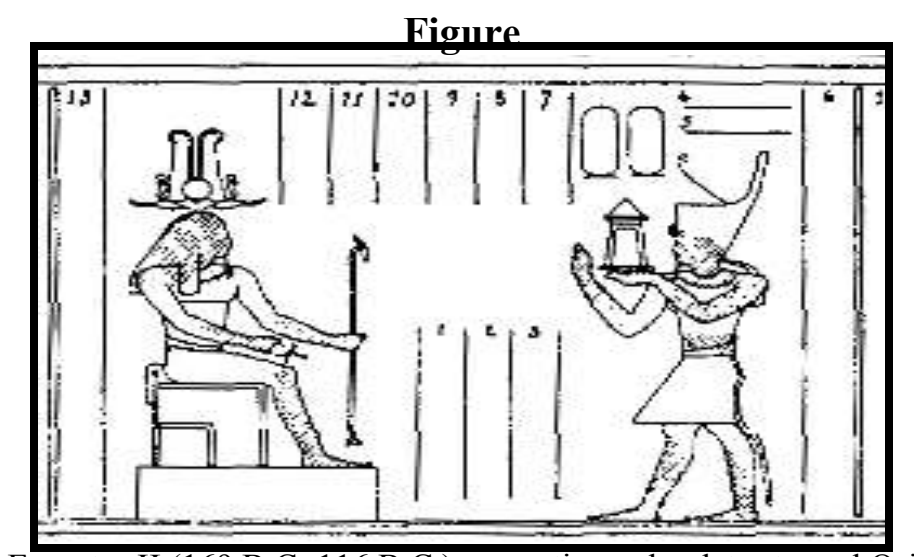

Fig.1. Ptolemy VIII Eurgetes II (169 B.C.-116 B.C.) presenting palm dates to god Osiris, Edfu temple, the exterior western wall of naos, fourth register, second scene

After; Chassinat, É., (1960). Le temple de Edfou X, Mémoires publiés par les membres de l'Institut français d'archéologie orientale 27, Le Caire, pl. 84

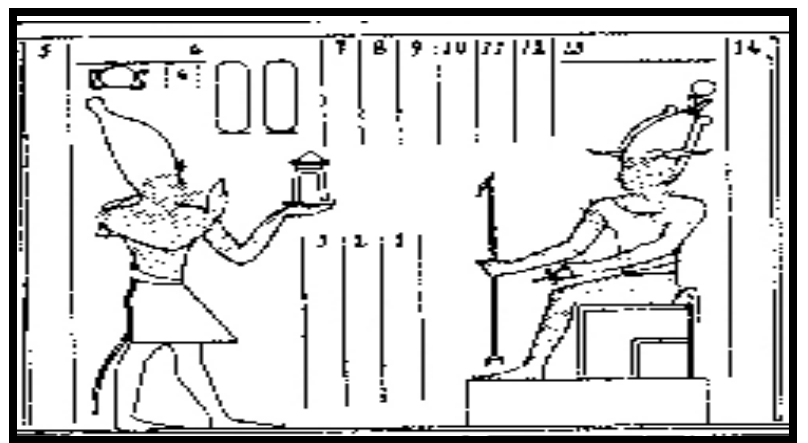

Fig.2. Ptolemy VIII Eurgetes II (169 B.C.-116 B.C.) presenting palm dates to god Osiris, Edfu temple, the exterior eastern wall of naos, fourth register, second scene After: Chassinat, É., (1960), tomeX, pl. 90.

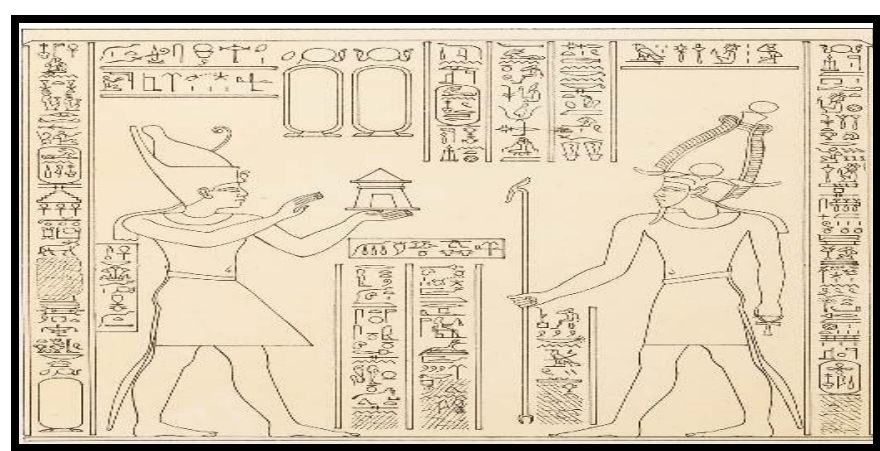

Fig.3. the Ptolemaic king (unidentified) presenting palm dates to god Osiris, temple of Denderah, the northern wall of the third eastern chamber (F) (Hall of Sokar), first register, third scene,

After: Mariette, A., (1870). Dendérah; description générale du grand temple de cette ville, Tome II, Librairie A.

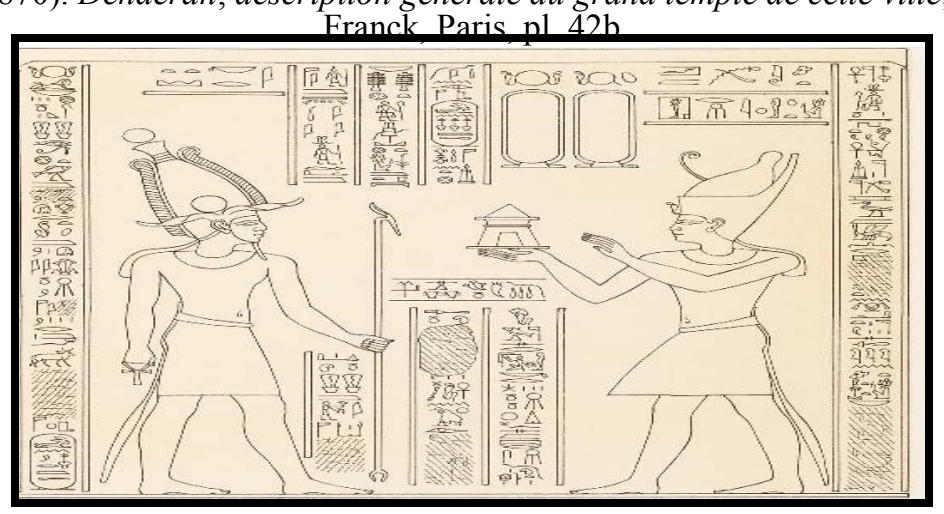

Fig.4. the Ptolemaic king (unidentified) presenting palm dates to god Osiris, temple of Denderah, the southern wall of the third eastern chamber (f) (Hall of Sokar), first register, third scene. After: Mariette, A., (1870), Tome II, pl. 42a 


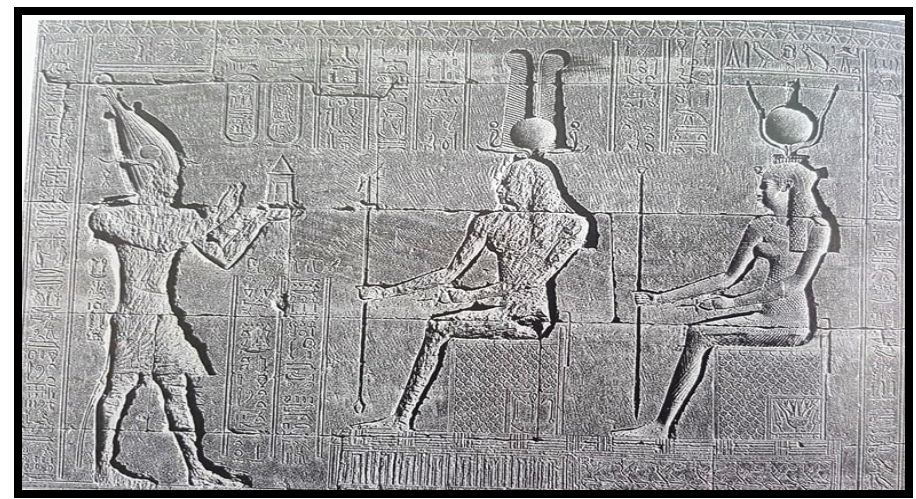

Fig. 5. Roman emperor Augustus (27 B.C-14 AD) presenting palm dates to Osiris and Isis, temple of Denderah, the exterior western wall of the naos $(\mathrm{H})$, fourth register, thirteenth scene

Cauville, S. (1997). Le temple de Dendara, Tome12, Institut français d'archéologie orientale, Le Caire, p. 279 , pl. 170

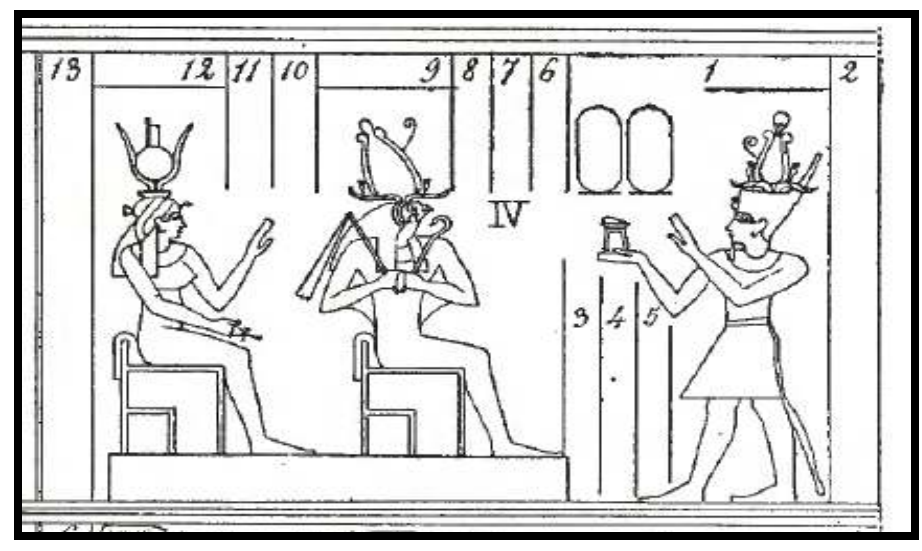

Fig.6. Roman emperor Augustus (27 B.C-14 AD) offering palm dates to Osiris and Isis, the temple of Isis of Philae, western exterior wall of the naos, second register, fourth scene

After: Bénédite, G. A. (1893). 'Le Temple de Philae', Mémoires publiés par les membres de l'Institut français d'archéologie orientale 13, Le Caire, pl. 33

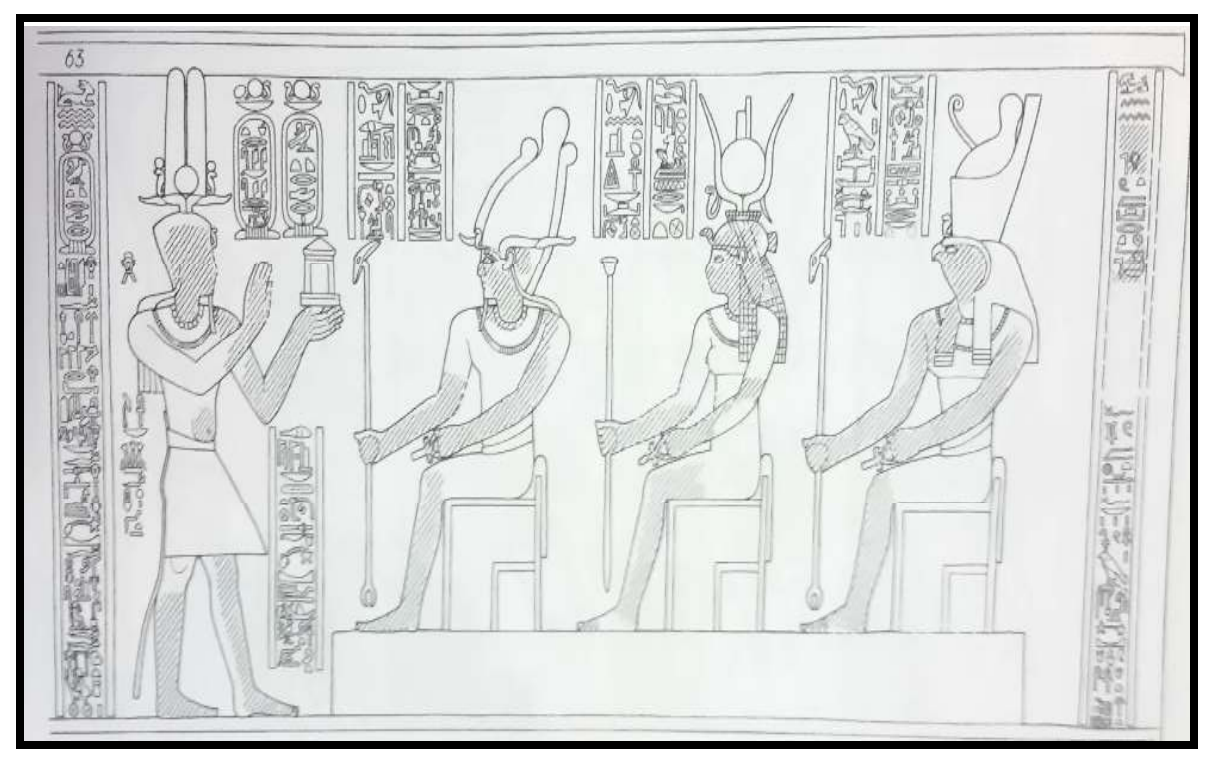

Fig.7. Roman emperor Tiberius (14 A.D.-37 A.D.) offering palm dates to Osiris, Isis, and Harendotes, the temple of Isis of Philae, the second eastern colonnade, the hall of Tiberius, the south wall, upper register

After: Kockelmann, H., and Winter, E., (2016). Philae III; Der Zweite Ostkolonnade des Tempels der Isis in Philae (Co II and Co II K), Teil 2:Tefeln, Verlag der Österreichischen Akademie der Wissenschaften, Wien, p. 117 , no. 116 , photo 63 


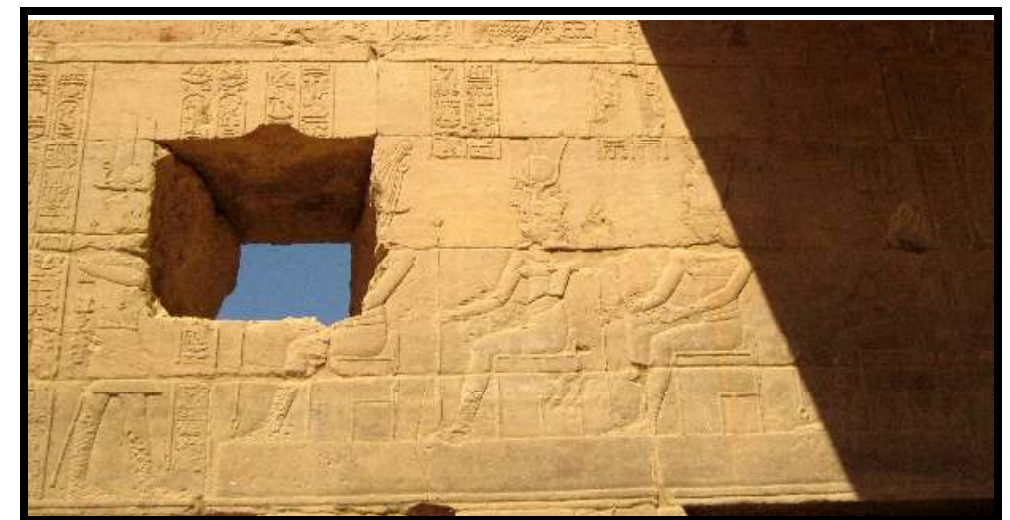

Fig.8. Roman emperor Tiberius (14 A.D.-37 A.D.) presenting palm dates to Osiris, Isis, Harendotus and Thoth of Pnubis, the temple of Isis of Philae, the wall of the western colonnade of Philae temple, upper register, $11^{\text {th }}$ scene ${ }^{(195)}$

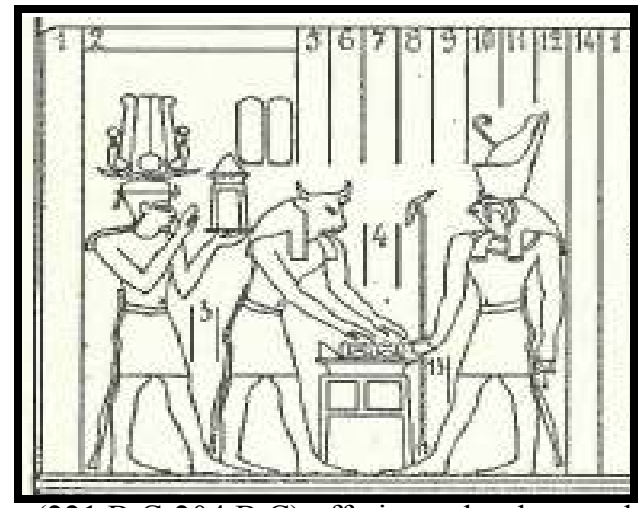

Fig.9. King Ptolemy IV Philopator (221 B.C-204 B.C) offering palm dates to both Horus and Apis, Edfu temple, the northern wall of the hall of offerings, first register, first scene

After: Rochemonteix, M., puis Chassinat, É., (1984-1987). Le temple de Edfou I, Mémoires publiés par les membres de l'Institut français d'archéologie orientale 10, Le Caire, pl. 35a

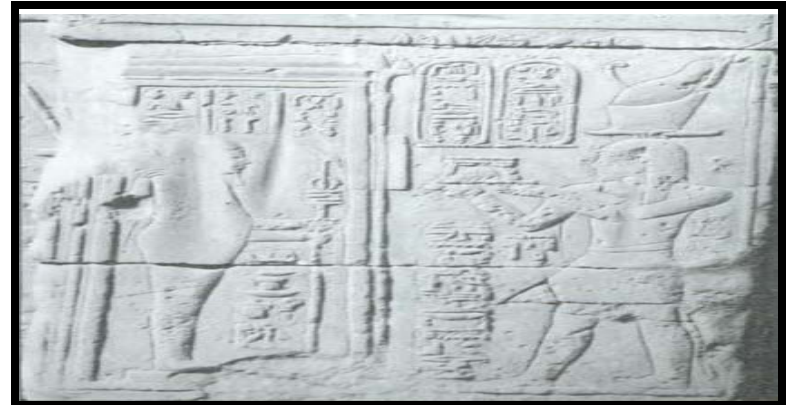

Fig. 10. Ptolemy VIII Eurgetes II (169 B.C.-116 B.C.) offering palm dates to Ptah, Tod temple

After: Thiers, Ch., (2000). 'Notes sur les inscriptions du temple Ptolémaïque et romain de Tôd (§1-4)', Egyptology at the Dawn of the Twenty-first Century: Archaeology; Proceedings of the Eighth International Conference of Egyptologists, vol. I: Archaeology, Ed. Hawass, Z., American University Press, Cairo, p. 517 , fig.1.

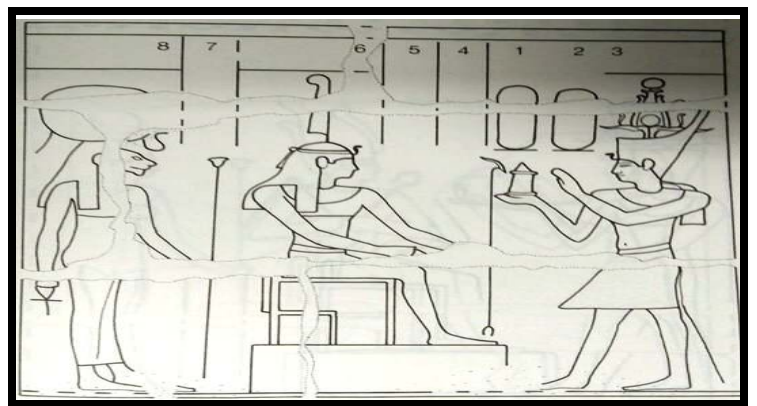

Fig.11. Roman Emperor Augustus (27 B.C-14 AD) presenting a jar of palm dates to Shu and Tefnut, In the façade of the central sanctuary, the northern wall, second register, temple of Qal'a

After: Pantalacci, L., (1990). Le Temple d'El-Qal 'a I, Relevés des scènes et des textes: sanctuaire central , sanctuaire nord, salle des offrandes, 1 à 112, Institut français d'archéologie orientale, Le Caire, n. 38 


\section{End Not}

(1) Wallert, I., (1962). Die Palmen im Alten Ägypten: Eine Untersuchung ihrer praktischen,symbolischen und religiöen Bedeutung, Verlag Burno Hessling, Berlin, p. 37; Erman, A. und Grapow, H., (1971). Wörtebuch der Ägyptischen Sprache, Band I, Akademie Verlag, Berlin, p. 461, no. 12-16; Darby, W. J., Ghalioungui, P., and Grivetti, L., (1977). Food: the Gift of Osiris, vol. 2, Academic Press, London-New York-San Francisco, p. 722; Cauville, S., (1980). 'Une offrande spécifique d'Osiris; le recpents a Dattes ( $m^{\complement} \underline{d} 3 \mathrm{n}$ bnr)', Revue d'égyptologie 32, Paris, p. 60.

${ }^{(2)}$ Darby, W. J., Ghalioungui, P., and Grivetti, L., (1977), p. 722; Cauville, S., (1980), p. 60; The Online LiddellScott-Jones Greek-English Lexicon http://stephanus.tlg.uci.edu/lsj/\#eid=24143\&context=lsj\&action=fromsearch accessed 10:11 AM 12.9.2018

${ }^{(3)}$ Cauville, S., (2012). Offerings to the Gods in Egyptian Temples, Peeters, Leuven-Paris-Walpole-MA, p. 107.

(4) Wallert, I., (1962), p. 37; Erman, A. und Grapow, H., (1971), p. 462, no. 1.

${ }^{(5)}$ Gardiner, A., (1957). Egyptian Grammar; Being an Introduction to the Study of Hieroglyphics, $3^{\text {rd }}$ ed., Griffith Institute, Ashmolean Museum, Oxford, p. 483, sign list M30: Wallert, I., (1962), p. 37.

${ }^{(6)}$ Sethe, K., (1960). Die Ägyptische Pyramidentexte nach den papierdrücken und Photographien des Berliner Museums, Band. I, Geaorg Olms Verbuchverhandlung, Leipzig, § 701c; Wallert, I., (1962), p. 38; Faulkner, R. O.,(1969). The Ancient Egyptian Pyramid Texts, The Clarendon Press, Oxford, p.132.

(7) Darby, W. J., Ghalioungui, P., and Grivetti, L., (1977), p. 724; Cauville, S., (1980), pp. 60-61; Issac, A.,(2010). The Effect of the Myth of Osiris on Some Religious and Funeral Beliefs and his Cult Centers according to the Recent Excavations till the end of the Late Period, part 1, (in Arabic), unpublished Phd. Thesis, Faculty of Archeology, Cairo University, Fayoum Branch, p. 122; Cauville, S., (2012), p. 107.

${ }^{(8)}$ Darby, W. J., Ghalioungui, P., and Grivetti, L., (1977), p. 724.

(9) Darby, W. J., Ghalioungui, P., and Grivetti, L., (1977), pp. 729-730.

${ }^{(10)}$ Issac, A., (2010), p. 122.

(11) Samples of dynastic dates stones and cakes are discovered and now preserved in Dokki Agricultural Museum in Cairo; Darby, W. J., Ghalioungui, P., and Grivetti, L., (1977), p. 724, figs. 18.11, 18.12; Wilkinson, A., (1998). The Garden in Ancient Egypt, the Rubricon Press, London, figs. 18.13, 18.14.

(12) Darby, W. J., Ghalioungui, P., and Grivetti, L., (1977), p. 724.

(13) Barta W., (1963). 'Die altaegyptische Opferliste von der Frühzeit bis zu Grieschiche Römische Epoche', Münchner ägyptologische Studien 3, Berlin, pp. 23-27; Cauville, S., (1980), p. 61; Issac, A., (2010), p. 122.

${ }^{(14)}$ Cauville, S., (2012), p. 107.

(15) Helck W., (1961-1970). 'Materialien zur Wirtschaftsgeschichte des Neuen Reiches', Band 5, AMAW, Wiesbaden, p. 760; Issac, A., (2010), p. 122.

(16) Gardinder, A. H., (1941). 'The Word $M^{\top} \underline{d} 3$ and its Various Uses', Journal of Egyptian Archaeology 26, Londres, p. 158; Erman, A. und Grapow, H., (1971), Band II, p.186, no. 15.

${ }^{(17)}$ Gardinder A. H., (1941), p. 158; Erman, A. und Grapow, H., (1971), Band II, p.120, no. 8.

(18) Gardinder A. H., (1941). p. 158.

(19) Von Bissing, F.W.F., (1956). La chambre des trois saisons du sanctuaire solaire du roi Rathourès (Ve Dynastie à. Abousir)', Annales du Service des Antiquités de l'Égypte 53, Le Caire, p. 338; pl. 14; Wallert, I., (1962), p. 112; Germer, R., (1986). 'Sykomore', Lexikon der Ägyptologie, Band VI, Ed. Otto E., Harrassowitz Verlag, Wiesbaden, col. 114.

${ }^{(20)}$ Von Bissing, F.W.F., (1956), p. 338; pl. 14; Wallert, I., (1962), p. 112.

(21) Wallert, I., (1962), p. 110-113; Germer, R.,(1986), col. 114.

${ }^{(22)}$ Roeder, G., (1913). “ Die ägyptische "Sargtexte" und das Totenbuch', Archiv für Reliogionswissenschaft 16, Leipzig, p. 81; De Buck, A., (1935-1961). The Egyptian Coffin Texts, vol. IV, The University of Chicago Press, Chicago- Illinois, 154; Faulkner, R.O., (1978). The Ancient Egyptian Coffin Texts, vol. I, $2^{\text {nd }}$ ed., Aris \& Phillips Ltd., Warminster, spell 354, p. 252; Wallert, I., (1962), p. 112; see also De Buck, A., (1935-1961), vol. III, $86 \mathrm{i} ; 128 \mathrm{~m}-129 \mathrm{~b}$.

${ }^{(23)}$ Cauville, S., (1980), p. 61.

(24) Wallert, I., (1962), p. 111.

${ }^{(25)}$ Wallert, I., (1962), p. 111; examples are found in; Rochemonteix, M., puis Chassinat, É., (1984-1987). Le temple de Edfou II, Mémoires publiés par les membres de l'Institut français d'archéologie orientale 10, Le Caire, pp. 50 (8); tome III , p. 231 (4); tome VIII , p. 34 (50; tome VII p. 199(2).

${ }^{(26)}$ Cauville, S., (1980), p. 47; Wallert, I., (1962), p. 38-41.

${ }^{(27)}$ Darby, W. J., Ghalioungui, P., and Grivetti, L., (1977), p. 725.

(28) In addition, since rebirth was related to fertility, the relationship between palm dates and certain gods especially, Osiris as well as other gods of fertility such as; Min, Bes or Priapus could be easily interpreted; Wallert, I., (1962), p. 110; Cauville, S., (1980), p. 62: For Min-Priapus see; Bonnet, H. (2000). Reallexikon, New York de Gruyter, Berlin, p. 464. 
(29) Gardiner, A. H. (1935). Hieratic Papyri in the British Museum, third series Chester Beatty Gift, vol. II, British Museum, London, pl. 6; Wallert, I., (1962), p. 109-110.

${ }^{(30)}$ Osiris was originally venerated as the god of agriculture and fertility. The famous struggle between Osiris and Seth referred mainly to the combat between fertility and dryness. In addition, Osiris controlled the Nile inundation, dug the canals, and erected flood dams. He was obviously relevant to fertility and the Nile inundation through its annual silt. Osiris is defined to be 'the new water' and the one who makes the fields green. In Egyptian myth, Osiris, after becoming the king of Egypt, was the first one who taught people the art of agriculture. He was especially connected with the Nile and its flood. The function of Osiris as a god of resurrection was clearly embodied through the Nile flood. The earth which is annually watered by the Nile flood symbolized Osiris resurrection and became one of his sacred insignia. The promise of Osiris resurrection was fulfilled through the annual Nile inundation. It is a cycle of vegetation, soil, water that expressed the rebirth of this deity. For further detail see; Erman, A. und Grapow, H., (1971), Band I, p. 207, no.12; Griffiths, J. G. (1982). 'Osiris', Lexikon der Ägyptologie, Band IV, Ed. Otto E., Harrassowitz Verlag, Wiesbaden, cols. 625628; Behaeghel, J. (1995). Osiris; Le Dieu Ressuscite, International Editeurs, Paris, pp. 101,103; Bonnet, H. (2000), pp. 571-572; Griffiths, , J. G., , (2001). 'Osiris', The Oxford Encyclopedia of Ancient Egypt, vol. 2, Ed., Redford, D., The American University Press, Cairo, p. 618; Bakhoum, S., (2002). Dieux Égyptiens Álexandrie sous les Antonins; Recherches numismatiques et historiques, CNRS Editions, Paris, pp. 125- 126; Leitz, C. (2002). Das Lexikon der ägyptischen Götter und Götterbezeichnungen, Band 2, Leuven, Peeters, pp. 528-570; Griffiths, J. G., (2002). 'Osiris', The Ancient Gods Speak, a Guide to Egyptian Religion, Ed., Redford, D., Oxford University Press, Oxford-New York, p. 306; Wilkinson, R. H., (2005). The Complete Gods and Goddesses of Ancient Egypt, American University Press, Cairo, pp. 118-119; Wilkinson, T. (2005). The Thames and Hudson Dictionary of Ancient Egypt, Thames and Hudson, London, p. 179.

${ }^{(31)}$ Thiers, Ch., (2000). 'Notes sur les inscriptions du temple Ptolémaïque et romain de Tôd (§1-4)', Egyptology at the Dawn of the Twenty-first Century: Archaeology; Proceedings of the Eighth International Conference of Egyptologists, vol. I: Archaeology, Ed. Hawass, Z., American University Press, Cairo, p. 518.

(32) Faulkner, R. O., (1964). A Concise Dictionary of Middle Egyptian, Oxford University Press, London, p.156; Erman, A. und Grapow, H., (1971), Band II, p. 469, no.5.

(33) Chassinat, E., (1968). Le mystère d'Osiris au mois de Khoaik I, Institut français d'archéologie orientale, Le Caire, p. 214; Cauville, S., (1980), p. 55-56, 61.

(34) Lindsay, J., (1968). Men and Gods on the Roman Nile, Fredrick Müller, London, p. 50.

${ }^{(35)}$ Erman, A. und Grapow, H., (1950), Band VI, p. VI, 26, no. 6; Faulkner, R. O., (1964), p. 277.

${ }^{(36)}$ Faulkner, R. O., (1964), p. 150; Erman, A. und Grapow, H., (1971), Band II, p.433, no. 25.

(37) Corteggiani, J. P. (2007). L'Égypte Ancienne et ses Dieux; Dictionnaire illustrié: Jean Piere Corteggianai: dessins de Laila Menassa, Fayard, Paris, p. 400.

${ }^{(38)}$ Many spells in the Pyramid Texts confirm that Osiris controlled over the cold water in the Otherworld. These spells describe his role as the only giver of cool water to the deceased king. In spell 33 of the Pyramid Texts, the king is identified with Osiris and owned accordingly his cool water; 'Oh (Osiris) king, take the cold water of yours, take the efflux which issued from you'. Spell 436 of the Pyramid Texts, which is called 'giving cool water', says 'You have your water you have your flood, the fluid which issued from the god, the exudation which issued form Osiris, your hands have been washed'; Sethe, K., (1960), Band I, § 24; Faulkner, R. O., (1969), p. 7. ${ }^{(39)}$ Bakhoum, S., (2002), p. 124.

${ }^{(40)}$ Wallert, I., (1962), pp. 41-44; Cauville, S., (2012), p. 107; Dates were used as a medication for purge and to regulate the urine and to eliminate the enigmatic $w h d w$. Mixing dates with other ingredients resulted in a medication to enhance fertility. Moreover, dates were involved in making bandages and fumigations for the belly. Dates were also part of an ophthalmic prescription from Asia. Pliny mentioned several medical prescriptions in which dates were one of the ingredients, their usa in healing bruises. According to Herodotus, the palm juice served to purify the abdominal cavity. In addition, classical authors realized the importance of the dates as an essential source for Vitamin A and Vitamin D; Pline, Historie Naturelle, XXIII, LI 97 and XXIII, LII, 98; Darby, W. J., Ghalioungui, P., and Grivetti, L., (1977), pp. 729-730; Cauville, S., (1980), pp. 61-62.

${ }^{(41)}$ Cauville, S., (1980), p. 62 ; Thiers, Ch., (2000), p. 518.

${ }^{(42)}$ Wilkinson, A., (1998). pp. 106-108; In the Thebean tomb of Tetaky (TT 15), two mww dancers are depicted with two obelisks, two sycamore trees, a palm garden, and god Osiris. This god is represented inside a great shrine. As for the three gods and three goddesses, the three sacred pools of purification, the four guardians of the entrance to paradise and Osiris, they are all depicted inside smaller shrines and forming by that way a sacred Ennead. Furthermore, in the mastaba of Idut, in the haulers of tekenu people are depicted reaching their arrival point, apparently a place in the Delta, which is here depicted as a place full of shrines and palm trees. For further detail, see; De Garis Davies, N., (1925). 'The Tomb of Tetaky at Thebes (No. 15)'. The Journal of Egyptian Archaeology, vol. 11, Londres, p. 17; Kanawati, N., and Abder-Raziq, M., (2003). Conspiracies in the Egyptian Palace: Unis to Pepy I, Routledge, New York, p. 49; Katerina, P., (2012). "The enigmatic "tekenu" An 
iconographical analysis of "tekenu" in tombs from the Old Kingdom to the Late Period', (https://core.ac.uk/download/pdf/16411052.pdf accessed 2.12.2016 10:10AM), pp. 42-43, 62-63, fig.56.

(43) Wilkinson, A., (1998), pp. 106-108.

(44) Refai, H., (2000). 'Überlegungen zur Baumgöttin', Bulletin de l'Institut français d'archéologie orientale 100, Le Caire, p. 383

${ }^{(45)}$ Sethe, K., (1960), Band I, § 701.c; Wallert, I., (1962), p. 38; Faulkner, R. O., (1969), p. 132; Cauville, S., (1980), p. 47; Issac, A., (2010), p. 122.

(46) Sethe, K., (1960), Band I, § 718c; Wallert, I., (1962), p. 109; Faulkner, R. O., (1969), p. 134; Bergman, J., (1979). 'Nut-Himmelsgöttin-Baumgöttin-Lebensgeberin', Religious Symbols and their Functions; based on Papers read at the Symposium on Religious Symbols and their Functions held at Abo on the $28^{\text {th }}-30^{\text {th }}$ of August 1978, Ed. Biezais, H., Almqvist and Wiksel, Stockholm, Scripta Instituti Donneriani Aboensis 10,Almqvist \& Wiksell International, Stockholm - Sweden, pp. 61-62; In addition, dates were related to the Egyptian god Min who was the one ' who feeds all'; Wallert, I., (1962), p. 109.

${ }^{(47)}$ De Buck, A., (1935-1961), vol. IV, 154a (325); Wallert, I., (1962), p. 110.

${ }^{(48)}$ Kees, H., (1983), Totenglauben und Jenseitsvorstellungen der alten Ägypter, Akademie-Verlag, Berlin, p. 85.

${ }^{(49)}$ Cauville, S., (1980), p. 61.

${ }^{(50)}$ Erman, A. und Grapow, H., (1971), Band V , p. 259, no. 7.

${ }^{(51)}$ Erman, A. und Grapow, H., (1971), Band IV, p. 198, no.9.

${ }^{(52)}$ Cauville, S., (1980), p. 62.

${ }^{(53)}$ Erman, A. und Grapow, H., (1971), Band II, p. 461, nr. 12; Cauville, S., (2012), p. 107.

(54) Erman, A. und Grapow, H., (1971), Band II, p. 462, no.1

${ }^{(55)}$ Erman, A. und Grapow, H., (1971), Band II, p. 458, no. 3; Cauville, S., (2012), p. 107.

(56) Darby, W. J., Ghalioungui, P., and Grivetti, L., (1977), p. 728; Cauville, S., (1980), p. 62; Cauville, S., (2012), p. 107.

(57) Cauville, S., (2012), p. 107-108.

${ }^{(58)}$ Cauville, S., (2012), pp. 107-108.

(59) Pliny, Historie Naturelle XIII, IX, 42; Täckolm, V., (1973). Flora of Egypt II, Otto Koeltz Antiquariat, Koenigstein, p. 210; Darby, W. J., Ghalioungui, P., and Grivetti, L., (1977), p. 728; Cauville, S., (1980), p. 62.

${ }^{(60)}$ Chassinat, E., (1968), p. 297; Cauville, S., (1980), pp. 47- 54, 63;

${ }^{(61)}$ Griffiths, J. G., (2002),p. 306; Wilkinson, R. H., (2005), p.122; This ritual was mentioned in one of the spells of the Coffin Texts that is called 'Spell for becoming barely'; Clark, R. T. R., (1959). Myth and Symbol in Ancient Egypt, Thames and Hudson, London, pp. 118-119.

${ }^{(62)}$ Bonneau, D., (1964). La crue du Nil, divinité égyptienne, à travers mille ans d'histoire (332 av.-641 ap. J.C.), Librairie C. Klincksieck, Paris, p. 249.

${ }^{(63)}$ Chassinat, E., (1968), pp. 292- 297; Cauville, S., (1980), pp. 47- 54, 63; the beds of Osiris were mainly mould taking the Osirian figure made of wood or pottery. They were filled with Nile mud and plants. In the festivals of Khoaik, The seeds were watered for nine days symbolizing apparently the ninth month of Osiris' gestation and germination. The beds of the deity were transported through on a boat that was lightened by three hundred sixty five torches. The voyage of Osiris lasted three years on the waters of the Nile. The boat set sail to the island where the tomb of Osiris was. The old moulded statue was replaced by the new one. This occurred on the thirtieth day of the festival. Finally, on the last day of celebration, the priests raised the sacred djed pillar of Osiris revealing his strength and stability for another year. For further detail see; Clark, R. T. R., (1959), p. 118; Bonneau, D., (1964). 251; Griffiths, J. G., (2002), p. 306.

${ }^{(64)}$ Issac, A., (2010), p.123; Chassinat, E., (1968), pp. 292- 297; Cauville, S., (1980), pp. 47- 54, 63.

(65) Cauville, S., (1980), p. 47-68; Cauville S. (1983). La Théologie d' Osiris à Edfou, Institut français d'archéologie orientale, Le Caire, p.176; Thiers, Ch., (2000), p. 517; Issac, A., (2010), p. 122.

${ }^{(66)}$ Cauville, S., (1980), pp. 47-50; Cauville S. (1983), p. 176, doc.77 and 78.

(67) Chassinat, É., (1928). Le temple de Edfou IV, Mémoires publiés par les membres de l'Institut français d'archéologie orientale 20, Le Caire, pl. 135, 4-16; Chassinat, É., (1960). Le temple de Edfou X, Mémoires publiés par les membres de l'Institut français d'archéologie orientale 27, Le Caire, pl. 84; Cauville, S., (1980), pp. 47-48; Cauville S. (1983), p. 176, doc.77; Porter, B. and Moss, R. L. B., (1991). Topographical Bibliography of Ancient Egyptian Hieroglyphic Texts, Reliefs, and Paintings, vol. VI, Griffith Institute, Oxford, p. $156(291-292)$.

${ }^{(68)}$ Chassinat, É., (1928) tome IV, p. 290 (18), 291 (13); Chassinat, É., (1960), tome X, pl. 90; Porter, B. and Moss, R. L. B., (1991), p. 158 (302-303); Cauville, S. (1980), pp. 49-50; Cauville S. (1983), p. 176, doc.78.

${ }^{(69)}$ Cauville S. (1983), p. 176, doc.77 and 78.

${ }^{(70)}$ It is thought that Osiris originated from god Andjeti ninth of Lower Egypt. He was a funerary as well as a fertility deity. His name was well attested in the Pyramid Texts in spell 219 'he who is in Andjet, chief of the nomes'. The conical crown of Andjet flanked with two 
feathers is obviously similar to the Osirian Atef Crown. For further detail see; Sethe, K., (1960), Band I, § 182a; Faulkner, R. O., (1969), p. 47; Erman, A. und Grapow, H., (1971), Band I, p. 207, no. 12; Griffiths, J. G., (1980). The Origins of Osiris and his Cult, Studies in the History of Religions 40, Ed., Van Voss, M.H., Shapre, E. J., and Werblowsky, R.J.Z., E.J. Brill, Leiden, pp. 130-138, 147; Hart, G., (1986). Dictionary of Egyptian Gods and Goddesses, Routledge, New York, pp. 18-19.

(70) Porter, B. and Moss, R. L. B., (1991), pp. 44, 77 (238-256); Cauville, S. (1997). Le temple de Dendara, Tome12, Institut français d'archéologie orientale, Le Caire, pp. 279, pl. 170.

${ }^{(71)}$ Chassinat, É., (1928), tome IV, pl. 135, 4-16; Chassinat, É., (1960), tome X, pl. 84; Cauville, S., (1980), p. 47; Issac, A., (2010), p. 123.

${ }^{(72)}$ Chassinat, É., (1928), tome IV, pl. 135, 4-16; Chassinat, É., (1960), tome X, pl.84; Cauville, S., (1980), p. 47-48; Issac, A., (2010), p. 123.

${ }^{(73)}$ Cauville, S., (1980), p. 47-48; Issac, A., (2010), p. 124.

(74) Chassinat, E., (1968), p. 15 -21; Issac, A., (2010), p. 124.

(75) Cauville, S., (1980), p. 49.

(76) Chassinat, É., (1928), tome IV, p. 290, 18-291, 13; Chassinat, É., (1960), tome X, pl. 90; Cauville, S., (1980), p. 49; Porter, B. and Moss, R. L. B., (1991), pp. 158,158 (302-303).

${ }^{(77)}$ Cauville, S., (1980), p. 49.

${ }^{(78)}$ Cauville, S., (1980), pp. 49-50.

${ }^{(79)}$ Cauville, S., (1980), pp. 49-50.

${ }^{(80)}$ Chassinat, É., (1934). Le Temple de Dendara II, Institut français d'archéologie orientale, Le Caire, pp. 145.9146.6 and pl. 127; Mariette, A., (1870). Dendérah; description générale du grand temple de cette ville, Tome II, Librairie A. Franck, Paris, pl. 42b; Derchain, Ph., (1963). 'La pêche à l'œil et les mystères d'Osiris à Dendara', Revue d'égyptologie 15, Louvain, Paris, pp. 11- 25; Cauville, S., (1980), pp. 51-52, 63; Porter, B. and Moss, R. L. B., (1991), pp. 52, 67 (183).

${ }^{(81)}$ Chassinat, É., (1934), p.145

${ }^{(82)}$ Cauville, S., (1980), p. 51.

${ }^{(83)}$ Chassinat, É., (1934), p. 145

${ }^{(84)}$ Cauville, S., (1980), p. 51.

${ }^{(85)}$ Chassinat, É., (1934), p. 145

(86) Cauville, S., (1980), p. 51.

${ }^{(87)}$ Chassinat, É., (1934), p.145

${ }^{(88)}$ Cauville, S., (1980), p. 51.

${ }^{(89)}$ Cauville, S., (1980), p. 51.

(90) Cauville, S., (1980), p. 51.

(91) Chassinat, É., (1934), p. 155,8-156,4 pl. 135: Mariette, A., (1870), Tome II, pl. 42a; Derchain, Ph., (1963), pp. 11 - 25; Cauville, S., (1980), pp. 51 51-52, 63; Porter, B. and Moss, R. L. B., (1991), pp. 52, 67(184).

${ }^{(92)}$ Cauville, S., (1980), p. 52.

(93) Cauville, S., (1980), p. 52.

(94) Cauville, S., (1980), p. 52.

(95) Bergmann, J. 'Isis', (1980). Lexikon der Ägyptologie, Band III, Ed. Otto E., Harrassowitz Verlag, Wiesbaden, cols. 191-194; Wilkinson, R. H.,(2005), pp.147-148.

(96) Rare sources mention the association between goddess Hathour and date palms; Wallert, I., (1962), p. 105; Dümichen, J.,(1865). Bauurkinde der Tempelanlagen von Dendera; in einem der geheimen Corridore im Innern der Tempelmauer aufgefunden und erläuternd mitgetheilt, J. C. Hinrchs'sche Buchhandlung, Leipzig, pl. 6, nr. 91, p.9.

(97) Allam, Sh., (1963). 'Beiträge zum Hathorkult (bis zum Ende des Mittleren Reiches', Münchner ägyptologische Studien 4, Berlin, pp. 90-104; Refai, H. (2000), p. 385;

${ }^{(98)}$ Refai, H., (2000), p. 384; Hornung, E. (1979). Das Totenbuch der Ägypter, Artemis Verlag, Zürich und München, p. 144.

${ }^{(99)}$ Bergmann, J. (1980), cols. 196-197; Wilkinson, R. H.,(2005), p. 145.

${ }^{(100)}$ Porter, B. and Moss, R. L. B., (1991), pp. 44, 77 (238-256); Cauville, S. (1997), p. 279, pl. 170

(101) According to the on-site collation of Fr. Daumas, this depicted the emperor that was identified by Cauville and Daumas to be the Roman emperor Nero (54 AD-64 AD). However, Cauville published the scene in the twelfth volume of Dendara temple. According to the inscribed cartouches, the depicted emperor is Augustus; Cauville, S., (1980), p. 52; Cauville, S. (1997), p. 279, pl. 170.

${ }^{(102)}$ Cauville, S., (1980), pp. 52- 53.

(103) Cauville, S., (1980), p. 53-54.

(104) Cauville, S., (1980), p. 54.

${ }^{(105)}$ Cauville, S., (1980), pp. 54, 61 
(106) Bénédite, G. A. (1893). 'Le Temple de Philae', Mémoires publiés par les membres de l'Institut français d'archéologie orientale 13, Le Caire, p. 107, 3-11 and pl. 33, tab. IV: Cauville, S., (1980), pp. 54-55; Porter, B. and Moss, R. L. B., (1991), p. 230, 245 (375-377).

(107) Cauville, S., (1980), p. 55.

${ }^{(108)}$ Cauville, S., (1980), p. 55.

${ }^{(109)}$ Cauville, S., (1980), p. 55-56..

(110) Cauville, S., (1980), p. 55.

${ }^{(111)}$ Cauville, S., (1980), p. 55-56.

${ }^{(112)}$ Bénédite, G. A. (1893), p. 107, 3-11; Cauville, S., (1980), p. 56.

${ }^{(113)}$ Bénédite, G. A. (1893), p. 107, 3-11; Cauville, S., (1980), p. 56; Thiers, Ch., (2000), p. 518.

${ }^{(114)}$ Bénédite, G. A. (1893), p. 107, 3-11; Cauville, S., (1980), pp. 57, 63.

(115) Kockelmann, H., and Winter, E., (2016). Philae III; Der Zweite Ostkolonnade des Tempels der Isis in Philae (Co II and Co II K), Teil 1:Text, Verlag der Österreichischen Akademie der Wissenschaften, Wien, p. 240, nr. 116, photo 63, Teil 2:Tafeln, p. 117, nr. 116, photo 63, ; Cauville, S., (1980), p. 59; Porter, B. and Moss, R. L. B., (1991), p. 212, 222 (150-151).

(116) Cauville, S., (1980), pp. 59-60.

${ }^{(117)}$ Cauville, S., (1980), p. 57.

${ }^{(118)}$ Kockelmann, H., and Winter, E., (2016), Teil 1, p. 240, no. 116, photo 63

${ }^{(119)}$ Kockelmann, H., and Winter, E., (2016), Teil 1, p. 240, no. 116, photo 63; Cauville, S., (1980), p. 60 j

${ }^{(120)}$ Cauville, S., (1980), p. 60.

${ }^{(121)}$ Cauville, S., (1980), p. 60; Thiers, Ch., (2000), p. 518.

${ }^{(122)}$ Cauville, S., (1980), p. 60.

(123) Cauville located this scene in the first eastern colonnade. However, Porter and Moss presented the right accurate location of the scene in the western colonnade of Philae temple see; Cauville, S., (1980), p. 57; Porter, B. and Moss, R. L. B., (1991), p. 204, 208 (26-34).

${ }^{(124)}$ Phiale photo 127, 627: Porter, B. and Moss, R. L. B., (1991), p. 204, 208 (33); Cauville, S., (1980), p. 57.

${ }^{(125)}$ Phiale photo 127, 627: Porter, B. and Moss, R. L. B., (1991), p. 204, 208 (33); Cauville, S., (1980), p. 5759.

${ }^{(126)}$ Cauville, S., (1980), p. 58.

${ }^{(127)}$ Cauville, S., (1980), p. 58.

(128) Cauville, S., (1980), p. 58.

${ }^{(129)}$ Cauville, S., (1980), p. 58; Thiers, Ch., (2000), p. 518.

${ }^{(130)}$ Cauville, S., (1980), p. 59.

(131) Simonet, J.-L., (1994). Le college des dieux maîtres d'autel. Nature et historie d'une figure tardive de la religion égyptienne, Orientalia Monspeliensia 7, Centre d'égyptologie de l'universite Paul-Valéry, Montpellier, p. 53; Wilson, P., (1997). A Ptolemaic Lexikon: A Lexicographical Study of the Texts in the Temple of Edfu, Orientalia Lovaniensia Analecta, Louvain, p. 417; Thiers, Ch., (2000), pp. 517-518.

${ }^{(132)}$ Rochemonteix, M., puis Chassinat, É., (1984-1987). tome I, pp. 471,(17), 472 (10), pl. 35a; Thiers, C., (2000), p. 517; Cauville, S., (1980), p. 62.

${ }^{(133)}$ Rochemonteix, M., puis Chassinat, É., (1984-1987), tome I, pp. 471 (17), 472 (10), pl. 35a; Cauville, S., (1980), p. 64.

${ }^{(134)}$ Cauville, S., (1980), p. 64.

${ }^{(135)}$ Rochemonteix, M., puis Chassinat, É., (1984-1987), tome I, p. 472; Cauville, S., (1980), p. 64; Simonet, J.L., (1994), pp. 49-50; Thiers, Ch., (2000), p. 518j

${ }^{(136)}$ Rochemonteix, M., puis Chassinat, É., (1984-1987), tome I, pp. 471,(17), 472 (10); Erman, A. und Grapow, H., (1971), Band I, p. 344, no. 14.

${ }^{(137)}$ Thiers, Ch., (2000), p. 517, fig.1; Thiers, Ch., (2003), Tôd: les inscriptions du temple ptolémaïque et romain II, Fouilles de l'Institut français d'archéologie orientale 18,2, p. 260, Text nr. 312.

${ }^{(138)}$ Thiers, Ch., (2000), p. 518, fig.1; Thiers, Ch., (2003), p. 260, Text nr. 312.

${ }^{(139)}$ Thiers, Ch., (2000), p. 518; Thiers, Ch., (2003), p. 260, Text nr. 312.

(140) Cauville, S., (1980), p. 62; Pantalacci, L., (1990). Le Temple d'El-Qal'a I, Relevés des scènes et des textes: sanctuaire central, sanctuaire nord, salle des offrandes, 1 à 112, Institut français d'archéologie orientale, Le Caire, n. 38; Thiers, Ch., (2000), pp. 517-518.

(141) Thiers, Ch., (2000), p. 517.

${ }^{(142)}$ Wilkinson, R. H., (2005). p. 119; see chapter 118 of the Book of the Dead; Von Dassow, E., (1998). The Egyptian Book of the Dead: The Book of Going Forth by Day - The Complete Papyrus of Ani Featuring Integrated Texts and Full-Color Images, $2^{\text {nd }}$ ed., Chronicle Books, San Francisco, p. 132.

${ }^{(143)}$ Hornung, E. (1979), pp. 59-60; Von Dassow, E., (1998), pp. 22-33. 
${ }^{(144)}$ It was thought that the ancient god Khenti Menti was a funerary deity whose character was identified with Osiris; Griffiths, J. G., (1982), col. 626.

(145) Brovarski, E.,(1984). 'Sokar', Lexikon der Ägyptologie, Band V, Ed. Otto E., Harrassowitz Verlag, Wiesbaden, cols. 1060-1061.

(146) Osiris was identified with god Sokar, the funerary Memphite god is early attested. The new god Osiris-Sokar spread widely by the late period; Griffiths, J. G. (1982), col. 629; Brovarski, E.,(1984), cols. 1060-1061; Wilkinson, R. H., (2005). p. 210.

${ }^{(147)}$ In Mendes, a city which was closely connected with Busiris the cult center of Osiris, a mixture of wheat, paste, incense were placed inside stone moulds and watered on the twelfth and the twenty-first days of Khoaik with water. After that, the whole mixture was placed inside golden moulds of the deity portrayed as a man wearing the White Crown. After being dried with the sun heat, the statue of Osiris as well as his moulds was placed in a boat illuminated with lamps to the tomb of the deity where they all were buried. Furthermore, similar golden moulds of god Sokar were also manufactured in this festival and buried on the last day of Khoaik. The two forms of Osiris were illustrated in the first northern chamber of Denderah temple. For further detail see; Mariette, A., (1870). Tome IV, pp. 68-90, pl. 31; Budge, W. E. A., (1911). Osiris and the Egyptian Resurrection, vol. 2, Dover Publications, New York, pp. 21-43, plates 39,40; Brovarski, E.,(1984), cols. 1060-1061.

${ }^{(148)}$ Chassinat, E., (1968), pp. 292- 297; Cauville, S., (1980), pp. 47- 54, 63.

${ }^{(149)}$ Cauville, S., (1980), p. 53.

(150) Erman, A. und Grapow, H., (1971), Band II, p. 518, nr.1, 2.

${ }^{(151)}$ Erman, A. und Grapow, H., (1971), Band IV, p. 495, no. 1; Cauville, S., (1980), p. 48, note. 10, and 63.

${ }^{(152)}$ Cauville, S., (1980), p. 48, note. 10, 63.Cauville, S., (1981). 'Chentayt et Merkhetès, des avatars d' Isis et Nephtys', Bulletin de l'Institut français d'archéologie orientale 81, Le Caire, pp. 21-40; Helck, W., (1984). 'Schentait', Lexikon der Ägyptologie, Band V, Ed. Otto E., Harrassowitz Verlag, Wiesbaden, cols. 580-581; Issac, A., (2010), p. 124.

${ }^{(153)}$ Cauville, S., (1980), pp. 51-52, 62; for further detail see; Derchain, Ph., (1963), pp. 11-25.

${ }^{(154)}$ Cauville, S., (1980), p. 63.

(155) Brovarski, E., (1984), col. 1064.

(156) A small temple dedicated to Harendotus was found on the island of Philae between the west stairway (V) and the Coptic Church (P), mainly to the north of the main temple of Isis. It is a square building that could be reached through six steps leading to a forecourt with an eastern colonnade, large chamber, and ends with a sanctuary linked by two rooms. See; Lyons, H.G.,(1896). A Report on the Island and Temples of Philae, Water low and Sons Limited Printers, London, pp. 31-32; Wilkinson, R. H., (2000). The Complete Temples of Ancient Egypt, Thames and Hudson, New York, pp. 214-215.

${ }^{(157)}$ Erman, A. und Grapow, H., (1971), Band III, p. 123, no.7

${ }^{(158)}$ Meeks, D., (1977). 'Harendotus', Lexikon der Ägyptologie, Band II, Ed. Otto E., Harrassowitz Verlag, Wiesbaden, col. 964.

${ }^{(159)}$ Meeks, D., (1977), col. 964.

${ }^{(160)}$ Meeks, D., (1977), col. 965.

(161) Erman, A. und Grapow, H., (1971), Band III, p.123, no.7

${ }^{(162)}$ Meeks, D., (1977), col. 965.

${ }^{(163)}$ Meeks, D., (1977), col. 965; see Griffiths, J.G., (1970). Plutarch's De Iside et Osiride, University of Wales, Cardiff, p. 345.

${ }^{(164)}$ Fischer, H.G., (1968). Dendera in the Third Millenium B.C. down to the Theban Domination of Upper Egypt, Locust Valley, New York, p. 147 Meeks, D., (1977), col. 965.

${ }^{(165)}$ Meeks, D., (1977), col. 965.

${ }^{(166)}$ Meeks, D., (1977), col. 965.

(167) Sethe, K., (1960), Band II, § 1406b; Faulkner, R. O., (1969), p. 218; Meeks, D., (1977), col. 965.

${ }^{(168)}$ Sethe, K., (1960), Band II, § 1406b; Faulkner, R. O., (1969), p. 218.

${ }^{(169)}$ Meeks, D., (1977), col. 965.

(170) Sethe, K., (1960), Band I, § 898 a-b; Faulkner, R. O., (1969), p. 157; Meeks, D., (1977), col. 965-966; see also Sethe, K., (1960), Band II, § 1685a, 633b, $1637 \mathrm{~b}$.

${ }^{(171)}$ De Buck, A., (1935-1961), vol. I, 2c, 51d,197k,201d, 223d,248c,285e; vol. II, 111a; vol. IV 204c, $280 \mathrm{c}$; vol. VI 216 b-c; vol. VIII, 111d, 209a; Meeks, D., (1977), col. 965.

${ }^{(172)}$ De Buck, A., (1935-1961), vol. I, 209 e; Faulkner, R.O., (1978), vol. I, p. 41.

(173) Philae Photo 627; Boylan, P., (1922). Thoth the Hermes of Egypt; a Study of Some Aspects of Theological Thought of Ancient Egypt, Oxford University Press, Oxford, p. 186; Junker, H., (1917). Onurislegende, A. Hölder, Wien, p.9; De Witt, C., (1951). Le Rôle et le Sens du Lion dans L' Égypte Ancienne, E. J. Brill, Leiden, p. 274; Pnubis: composed of the initial P which stood for ' $p r$ ' meaning 'the abode of' and for the word 'Nubis' which means 'the sycamore tree'. This city could be identified Kurteh and Ofendineh. However, Ptolemy 
mentions a city called Pnubis in Upper Nubia: Weigall, A., (1907). Report on the Antiquities of Lower Nubia, Oxford University Press, Oxford, p. 86.

(174) Wallert, I., (1962), pp. 98-99; for further detail see; Säve-Söderbergh, S. T., (1957). Four Eighteenth Dynasty Tombs, Griffith Institute, Oxford, p. 14, n.1.

${ }^{(175)}$ Wallert, I., (1962), pp. 89-90.

(176) Petrie, Fl.,(1880). Neukratis I, Egyptian Exploration Fund, London, pl. 37, nr. 136; Newberry, P. E., (1906). Scarabs; an Introduction to the study of Egyptian Seals and Signet Rings, Archibald Constable and CO LTD, London, pl. 42; nr. 28; Wallert, I., (1962), p. 99.

${ }^{(177)}$ Wallert, I., (1962), pp. 98-99; I, 3, b.

(178) Vercoutter, J., (1975), 'Apis', Lexikon der Ägyptologie, Band I, Ed. Otto E., Harrassowitz Verlag, Wiesbaden, cols. 339-340; Wilkinson, R. H., (2005), pp. 170-171.

(179) Sethe, K., (1960), Band I, § 701.c; Faulkner, R. O., (1969), p. 132;

${ }^{(180)}$ Vercoutter, J., (1975), cols. 340-241; Wilkinson, R. H., (2005), pp. 170-171.

(181) According to Chr. Thiers, being the main god of the temple of Tod, the presence of Montou would have been more acceptable, integrating with the Osirian nature of this type of offering in Edfu temple.The iconography of Ptah Tatenen appeared in the temple of Tod twice in scene no. 131, 237; Thiers, Ch., (2000), p. 518.

${ }^{(182)}$ Wallert, I., (1962), p. 111.

(183) A late papyrus described her struggle with the sun. Thus, she flew to Nubia in the shape of a lioness deity. God Thoth was the one who could convince Tefnut to return back to Egypt again; Wilkinson, R. H., (2005), p. 182.

${ }^{(184)}$ Wilkinson, R. H., (2005), p. 129.

(185) Among the treasures of Tutankhamon (1336-1327 B.C.), there is an ivory-head rest that represented the shape of the two lions of Shu and Tefnut. Between them, there is a male figure, probably representing the sun, resting the sleeper's head on his upraised hands; Pinch, G., (2002). Egyptian Mythology: A Guide to the Gods, Goddesses, and Traditions of Ancient Egypt, Oxford University Press, London, p. 197; Wilkinson, R. H., (2005), pp. 129-130, 183.

${ }^{(186)}$ Yesterday and today were depicted in the shape of two identical lions in ancient Egypt. In the $17^{\text {th }}$ chapter of the Book of the Dead, the two lions became identified with Shu and Tefnut. They are depicted seated back to back and supporting the horizon sign and over it the sign of the sky. The right-handed lion is called sf $\left.\right|^{\odot} \odot$ which means 'yesterday', while the other lion on the left is called $d w 3(i) t \times 1$ 'to-day'. The accompanying text says; $n w . k$ sf rh kwi $d w 3 w$, "I am yesterday, I know to-day"; Faulkner, R. O., (1964), pp. 224, 310; Erman, A. und Grapow, H., (1971), Band IV, p. 113, no. 16; Band V, p. 424, no. 7; Hornung, E. (1979), pp. 60-61, abb. 8a.

${ }^{(187)}$ Chassinat, E., (1968), pp. 292- 297; Cauville, S., (1980), pp. 47- 54, 63.

(188) Derchain, Ph., (1963), pp. 11- 25; Cauville, S., (1980), p. 51; 51-52, 63

(189) Derchain, Ph., (1963), pp. 11- 25;Cauville, S., (1980), p. 51; 51-52, 63-64.

${ }^{(190)}$ Cauville, S., (1980), p. 62: Issac, A., (2010), p. 123; Cauville, S., (2012), p. 102.

(191) Cauville, S., (2012), p. 107.

${ }^{(192)}$ Cauville, S., (1980), p. 63.

(193) Thiers, Ch., (2000), p. 518.

(194) Budge, W. E. A., (1911), pp. 113-114.Gardiner, A., (1957), p. 500, Q2; Erman, A. und Grapow, H., (1971), Band I, p. 359, no.5.

${ }^{(195)}$ I owe my gratitude to Dr. Ali Abdelhalim Ali, Associate Professor in Ain Shams University who kindly captured this photo. 